\title{
Motif co-regulation and co-operativity are common mechanisms in transcriptional, post-transcriptional and post-translational regulation
}

\author{
Kim Van Roey ${ }^{1,2}$ and Norman E. Davey ${ }^{3^{*}}$
}

\begin{abstract}
A substantial portion of the regulatory interactions in the higher eukaryotic cell are mediated by simple sequence motifs in the regulatory segments of genes and (pre-)mRNAs, and in the intrinsically disordered regions of proteins. Although these regulatory modules are physicochemically distinct, they share an evolutionary plasticity that has facilitated a rapid growth of their use and resulted in their ubiquity in complex organisms. The ease of motif acquisition simplifies access to basal housekeeping functions, facilitates the co-regulation of multiple biomolecules allowing them to respond in a coordinated manner to changes in the cell state, and supports the integration of multiple signals for combinatorial decision-making. Consequently, motifs are indispensable for temporal, spatial, conditional and basal regulation at the transcriptional, post-transcriptional and post-translational level. In this review, we highlight that many of the key regulatory pathways of the cell are recruited by motifs and that the ease of motif acquisition has resulted in large networks of co-regulated biomolecules. We discuss how co-operativity allows simple static motifs to perform the conditional regulation that underlies decision-making in higher eukaryotic biological systems. We observe that each gene and its products have a unique set of DNA, RNA or protein motifs that encode a regulatory program to define the logical circuitry that guides the life cycle of these biomolecules, from transcription to degradation. Finally, we contrast the regulatory properties of protein motifs and the regulatory elements of DNA and (pre-)mRNAs, advocating that co-regulation, co-operativity, and motif-driven regulatory programs are common mechanisms that emerge from the use of simple, evolutionarily plastic regulatory modules.
\end{abstract}

Keywords: Motifs, Cis-regulatory elements, RNA motifs, Short linear motifs, SLiMs, Co-regulation, Co-operativity, Regulation, Modularity

\section{Background}

The life of a gene product, from transcription to degradation, is controlled by a series of regulatory decisions. How does the cell decide when to make a transcript? Does a transcript get translated, stored, decayed or transported to a specific subcellular location? After translation, where is a protein localised, and what complexes should it join? Ultimately, when is a protein degraded? The outcome of this decision-making process is cell state dependent and, consequently, requires the integration of vast amounts of

\footnotetext{
* Correspondence: norman.davey@ucd.ie

${ }^{3}$ Conway Institute of Biomolecular and Biomedical Sciences, University College Dublin, Dublin 4, Ireland

Full list of author information is available at the end of the article
}

information that is encoded in the local abundance and functional state of a multitude of biomolecules acting as cell state sensors and transmitters. Recent advances in our understanding of cell regulation have suggested that a substantial portion of the interactions that facilitate conditional and dynamic cellular decision-making in higher Eukaryotes are mediated by compact and degenerate interaction modules known as motifs (short linear motifs (SLiMs) in proteins, RNA motifs in RNA and regulatory elements in DNA) [1-5]. The term motif denotes a repeated figure or design and, in motif biology, the occurrence of a given class of motif in a set of unrelated biomolecules led to the appropriation of the term to refer

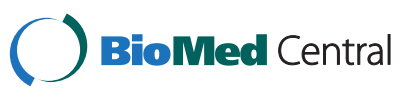

(c) 2016 Van Roey and Davey. Open Access This article is distributed under the terms of the Creative Commons Attribution 4.0 International License (http://creativecommons.org/licenses/by/4.0/), which permits unrestricted use, distribution, and reproduction in any medium, provided you give appropriate credit to the original author(s) and the source, provide a link to the Creative Commons license, and indicate if changes were made. The Creative Commons Public Domain Dedication waiver (http://creativecommons.org/publicdomain/zero/1.0/) applies to the data made available in this article, unless otherwise stated. 
to a recurrent pattern of nucleotides or amino acids that corresponds to an autonomous functional module.

The higher eukaryotic cell has an extensive repertoire of DNA, RNA and peptide motifs that function as dynamic binding modules in complex formation, recruiters of basal regulatory pathways, or receivers of cell state information through association with or modification by their interaction partner [6-8]. These motifs control many aspects of transcriptional (recruiting the basal transcription machinery and transcriptional regulators to the numerous promoters, enhancers, silencers and insulators [6, 9-12]), post-transcriptional (controlling protein production by modulating pre-mRNA splicing; mRNA stability, storage and localisation; and microRNA (miRNA) recruitment $[7,13-17]$ ) and post-translational regulation (controlling a protein's stability, localisation, modification state and complex association $[1,8,18,19]$ ) (Table 1 ). The regulatory regions of most genes, (pre-)mRNAs and proteins have extensively exploited the available motif repertoire $[8,20$, 21 ] and each biomolecule contains a distinct set of motifs that encode unique regulatory programs tuned to govern the life cycle of the biomolecule [22]. These motifs often occur with high densities as the compact footprint of sequence motifs allows multiple functional modules to be encoded in a short polypeptide or polynucleotide segment $[2,4,5,23,24]$.

Experimental and bioinformatics studies are beginning to offer an insight into the mechanisms driving motif acquisition [4, 25-34]. Many instances are undoubtedly the product of duplication or recombination [25, 31, 35-37]. Conversely, substantial indirect evidence from the comparison of motif presence in different species suggests that motifs can be gained and lost relatively rapidly in homologous regions [26, 27, 31, 34, 38-41]. This observed evolutionary plasticity, in association with their degenerate nature and the limited number of affinity- and specificitydetermining residues in a motif, led to the hypothesis that novel motif instances are often acquired through ex nihilo motif evolution by point mutations, insertions or deletions $[27,31,32,42]$. However, catching evolution in the act is difficult. For SLiMs, a serine to glycine mutation in Leucine-rich repeat protein SHOC-2 (SHOC2), which results in a novel myristoylation motif and causes aberrant SHOC2 localisation, provides the sole experimentally characterised example of ex nihilo motif birth on the protein level [42]. The mutation is found in several patients with Noonan-like syndrome and for some, the sequence variation is present in neither parents. Thus, the birth of this novel motif is often the result of a germline mutation. A similar mechanism of ex nihilo motif acquisition has been hypothesised for nucleotide motifs [31-33]. Indeed, the probability of a motif occurring by chance at a given position is equivalent for the motifs of the three major classes of biomolecule.
Consequently, though the three major types of motif are physicochemically distinct they share a similar evolutionary plasticity that has resulted in the ubiquity that gave them their shared name.

The human proteome contains thousands of motifbinding proteins. The current census of nucleotide motif-binding proteins stands at 1400 DNA-binding proteins [43] and $\sim 850$ RNA-binding proteins [44]. The number of SLiM-binding proteins remains to be elucidated, however, given the distribution of known SLiMbinding and -modifying domains in the human proteome, it is likely to be in a similar range $[8,45]$. This would suggest that upwards of $20 \%$ of the human proteome might consist of motif-binding proteins. Furthermore, 2000 human RNA motif-recognising miRNAs have been annotated [46]. Hundreds of distinct classes of motifs recognised by motif-binding biomolecules have been characterised to date [6-8]. The simplicity of motif acquisition has driven the proliferation of motifs of widespread utility and, for several motif classes, experimentally characterised motif instances are present in tens of biomolecules $[6,8,47]$. For a handful of classes, hundreds, or even thousands, of motif instances are known [11, 48, 49]. On the protein level, the high motif density of wellcharacterised biomolecules [23], the extensive regions of intrinsic disorder [50] (where SLiMs are the predominant functional module type $[1,51]$ ) and the numerous SLiMbinding domains [45] suggest extensive motif use in complex organisms. Recently, Tompa et al. hypothesised that the human proteome may contain up to a million SLiMs [22], however, the actual number of motifs is unknown. The reason is simple, SLiM discovery is difficult: computational approaches have high false positive rates and experimental techniques must overcome the transience of SLiM-mediated interactions, extensive SLiM co-operativity, redundancy and weak phenotypes [52]. However, recent advances in experimental discovery techniques, particularly high-throughput discovery methods, will hopefully rectify this in the coming decade [53].

In this review, while focusing on SLiMs, we aim to highlight the similarities in the use of motif co-regulation and co-operativity in transcriptional, post-transcriptional and post-translational regulation. We discuss how the evolutionary plasticity of sequence motifs facilitated their proliferation and supported the evolution of extensive networks of co-regulation. We examine how the ability to readily add a functional module without disturbing a pre-existing regulatory interface promotes high functional density and how motifs can functionally modulate each other to create decision-making interfaces capable of integrating cell state information. Finally, we consider how multiple motifcontaining interfaces in the same biomolecule collaborate to create unique regulatory programs. 
Table 1 Representative examples of protein, RNA and DNA motifs

\begin{tabular}{|c|c|c|c|}
\hline Motif type & Example motif & Consensus sequence $^{a}$ & Function \\
\hline \multicolumn{4}{|l|}{ Protein short linear motifs } \\
\hline \multirow{5}{*}{$\begin{array}{l}\text { Ligand - promote complex } \\
\text { formation }\end{array}$} & SH3 ligand & $\operatorname{PxxPx}[\mathrm{KR}]$ & Complex formation with SH3 domains [195] \\
\hline & Nuclear receptor box & $L x x L L$ & Complex formation with Nuclear receptors [196] \\
\hline & LD motif & {$[\mathrm{LV}][\mathrm{DE}] \times[\mathrm{LM}][\mathrm{LM}] \times \mathrm{x} \mathrm{L}$} & Complex formation with FAT domains [197] \\
\hline & LXCXE motif & {$[\mathrm{IL}] \times \mathrm{C} \times \mathrm{E}$} & Complex formation with Rb [198] \\
\hline & RGD motif & RGD & Complex formation with Integrin family members [199] \\
\hline \multirow{5}{*}{$\begin{array}{l}\text { Localisation - recruit targeting and } \\
\text { transport pathways to control } \\
\text { protein localisation }\end{array}$} & $\begin{array}{l}\text { Nuclear Export Signal } \\
\text { (NES) }\end{array}$ & $\Phi \times \times \Phi \times x \times \Phi \times \times \Phi \times \Phi$ & Translocation from the nucleus to the cytoplasm [200] \\
\hline & $\begin{array}{l}\text { KDEL ER retrieval } \\
\text { signal }\end{array}$ & {$[K H] D E L-C O O H$} & $\begin{array}{l}\text { Translocation from the Golgi to the endoplasmatic } \\
\text { reticulum (ER) [201] }\end{array}$ \\
\hline & Ciliary targeting signal & $\mathrm{RV} \times \mathrm{P}$ & Transport to the plasma membrane of the cilia [202] \\
\hline & $\begin{array}{l}\text { Peroxisomal targeting } \\
\text { signal }\end{array}$ & {$[K R H] \times x \Phi \$$ or $[K R H] \Phi \$$} & Import into the peroxisomal lumen [203] \\
\hline & $\begin{array}{l}\text { Tyrosine endocytic } \\
\text { signal }\end{array}$ & $Y x \times \Phi$ & Directs endocytosis of membrane proteins [204] \\
\hline \multirow{5}{*}{$\begin{array}{l}\text { Enzyme recruitment - recruit } \\
\text { enzymes to the protein/complex } \\
\text { to modify/demodify a site distinct } \\
\text { from the bound motif }\end{array}$} & Cyclin docking motif & {$[\mathrm{RK}] \times \mathrm{L} \mathrm{x}_{\{0,1\}}[\mathrm{LF}]$} & Recruitment of the Cyclin-Cdk holoenzyme [205] \\
\hline & PP1 docking motif & $\mathrm{RV} x \mathrm{~F}$ & Recruitment of the PP1 phosphotase holoenzyme [206] \\
\hline & $\begin{array}{l}\text { Tankyrase docking } \\
\text { motif }\end{array}$ & $\operatorname{Rxx}[\mathrm{PGAV}][\mathrm{DEI}] \mathrm{P}] \mathrm{G}$ & $\begin{array}{l}\text { Recruitment of the Tankyrase poly- } \\
\text { (ADP-ribose) polymerase [207] }\end{array}$ \\
\hline & USP7 docking motif & PxxS & Recruitment of the USP7 deubiquitylating enzyme [208] \\
\hline & NEDD4 docking motif & PPXY & Recruitment of the NEDD4 ubiquitylating enzyme [209] \\
\hline \multirow{5}{*}{$\begin{array}{l}\text { Stability - recruit E3 ubiquitin } \\
\text { ligases and promote substrate } \\
\text { polyubiquitylation to control } \\
\text { protein stability }\end{array}$} & APC/C D box degron & $\operatorname{RxxLxx\Phi }$ & APC/C E3 ubiquitin ligase [210] \\
\hline & PIP degron & $\Phi[\mathrm{ST}] \mathrm{D}[\mathrm{FY}][\mathrm{FY}] \mathrm{xxx}[\mathrm{KR}]$ & Recruitment of the Cdt2 CRL4 E3 ubiquitin ligase [211] \\
\hline & Fbw7 degron & $\mathrm{p}^{\mathrm{TPxx}}[\mathrm{ST}]$ & Recruitment of the Fbw7 SCF E3 ubiquitin ligase [212] \\
\hline & $\begin{array}{l}\text { Oxygen dependent } \\
\text { VHL degron }\end{array}$ & {$[I L] A_{\circ} P x_{\{6,8\}} \Phi \times \Phi$} & $\begin{array}{l}\text { Recruitment of von Hippel-Lindau protein (pVHL) } \\
\text { containing E3 ubiquitin ligase [213] }\end{array}$ \\
\hline & MDM2 degron & $F x x \times W x x \Phi$ & $\begin{array}{l}\text { Recruitment of the MDM2 ubiquitin } \\
\text { ligase [214] }\end{array}$ \\
\hline \multirow{5}{*}{$\begin{array}{l}\text { Modification - act as sites of } \\
\text { moiety attachment/removal, } \\
\text { isomerisation or cleavage }\end{array}$} & $\begin{array}{l}\text { PIKK phosphorylation } \\
\text { site }\end{array}$ & ([ST])Q & Phosphorylation by PIKK family kinases [215] \\
\hline & Pin1 isomerisation site & $p[S T](P)$ & $\begin{array}{l}\text { Isomerisation by the Pin1 phosphorylation-dependent } \\
\text { prolyl isomerase [216] }\end{array}$ \\
\hline & N-Glycosylation site & $N x([S T])$ & Glycosylation by Oligosaccharyltransferase [217] \\
\hline & $\begin{array}{l}\text { Caspase- } 3 \text { and }-7 \\
\text { cleavage motif }\end{array}$ & {$[D E] \times x D \mid[A G S]$} & Cleavage by Caspase family proteases [218] \\
\hline & Myristoylation site & $\mathrm{NH} 2_{2}-\mathrm{M}(\mathrm{G}) \times x \times[\mathrm{AGSTCN}]$ & $\begin{array}{l}\text { Myristoylation by Myristoyl-CoA:protein } \\
\text { N-myristoyltransferase [219] }\end{array}$ \\
\hline \multicolumn{4}{|l|}{ RNA motifs } \\
\hline Stability & $\begin{array}{l}\text { Adenosine and } \\
\text { uridine (AU)-rich } \\
\text { elements (ARE) }\end{array}$ & AUUUA & $\begin{array}{l}\text { Recruits positive and negative regulators of mRNA } \\
\text { stability [13] }\end{array}$ \\
\hline Splicing & $5^{\prime}$ splice junction & AG/GURAGU & $\begin{array}{l}\text { Recruits splice site recognising U1 snRNA component } \\
\text { of the spliceosome [14] }\end{array}$ \\
\hline Modification & Polyadenylation signal & AUUAAA & $\begin{array}{l}\text { Recruits cleavage and polyadenylation specificity } \\
\text { factor (CPSF) to cleave and polyadenylate 3'-UTRs [15] }\end{array}$ \\
\hline Localisation & $\begin{array}{l}\text { Muscleblind binding } \\
\text { motifs }\end{array}$ & YGCUKY & Targets mRNAs to membranes [16] \\
\hline miRNA recruitment & $\begin{array}{l}\text { miR-125b miRNA } \\
\text { response element }\end{array}$ & CUCAGGG & Regulates expression of mutiple proteins [17] \\
\hline
\end{tabular}


Table 1 Representative examples of protein, RNA and DNA motifs (Continued)

\begin{tabular}{|c|c|c|c|}
\hline \multicolumn{4}{|l|}{ DNA regulatory elements } \\
\hline Basal machinery recruitment & TATA box & TATAAAA & $\begin{array}{l}\text { Recruitment of the basal transcription machinery to } \\
\text { the core gene promoter required for initiation of } \\
\text { transcription [9] }\end{array}$ \\
\hline Promoters/Enhancers & $\begin{array}{l}\text { CCAAT/enhancer } \\
\text { binding protein } \\
\text { (C/EBP) site }\end{array}$ & CCAAT & Promotion of gene expression [10] \\
\hline Silencers/Insulators & $\begin{array}{l}\text { CCCTC-binding factor } \\
\text { (CTCF) } \\
\text { binding site }\end{array}$ & CCGCGNGGNGGCAG & $\begin{array}{l}\text { Diverse functions including acting as a transcriptional } \\
\text { repressor and insulator [11] }\end{array}$ \\
\hline Endonucleases & EcoRI restriction site & G|AATTC & Sequence specific cleavage of DNA [12] \\
\hline
\end{tabular}

\section{Motif co-regulation}

Data from genome sequencing projects has failed to reveal the anticipated correlation between biological complexity and proteome size [54]. This led to the hypothesis that the emergence of increasingly complex organisms was facilitated by an increase in regulation rather than protein number [55-58]. But what supports the increased complexity of regulation in the higher eukaryotic cell?

One key feature of eukaryotic regulation is the extensive reuse of specialised regulatory pathways. The ease of motif acquisition, facilitated by their evolutionary plasticity, makes them the ideal module to simplify access to systems of widespread utility, and evolution appears to have exploited this extensively. Accordingly, many motifs encode the ability to recruit components of these regulatory systems (Table 1). The intrinsic evolutionary properties of motifs have facilitated the evolution of large networks of biomolecules that bind to a single motif-binding hub acting as recognition element for the regulatory machinery (for instance, gene promoters containing hypoxia response elements (HREs) recruit the HIF-1 complex to induce expression of genes involved in the response to limited oxygen conditions [59]; coregulation of the translation and stability of mRNAs encoding proteins involved in iron metabolism by ironresponsive elements (IREs) in the untranslated regions (UTRs) that bind iron regulatory proteins depending on iron availability [60]; concerted degradation of cell cycle regulatory proteins in a cell cycle phase-dependent manner through recognition of specific degron motifs by the Anaphase-Promoting Complex/Cyclosome (APC/C) ubiquitin ligase [61]). As a result, instances of the same motif class are regularly present in multiple distinct biomolecules $[8,30,48,62]$ (a motif class defines the set of motifs that recognise a single motif-binding pocket on a specific biomolecule). Interestingly, these networks are evolutionarily dynamic and differ between even closely related species [27, 41, 63]; however, it appears that once a functionally valuable motif-accessible system is in place, additional biomolecules come under the control of these systems, thereby extending the regulatory networks (Fig. 1a) [48]. Most of the more abundant motifs link biomolecules to the molecular machinery that performs important basal house keeping functions. Basal functions can be required by thousands of biomolecules and consequently many of the motifs that facilitate these functions are ubiquitous (for example, the motifs that recruit the basal transcription, splice site recognition and protein translocation machinery $[48,49,62]$ ) (Fig. 1b). An important subset of the regulatory machinery is the conditionally, temporally or spatially restricted motifbinding molecules that transmit cell state information to the motif-containing biomolecule (Fig. 1c and d). The cell contains numerous motif-accessible pathways that allow biomolecules to integrate cell state information in their interfaces to respond appropriately and in a coordinated manner to changes in their environment (for example, fluctuations in calcium levels [64-66] (Fig. 1f), transitions of cell cycle phase [41, 67-69] or detection of DNA damage $[70,71])$. On the protein level, motif-binding pockets can also recruit several distinct motif-containing regulatory proteins to a complex. In these cases, the motif facilitates the construction of functionally distinct assemblies around a constant complex core, for example, the recruitment of PIP box motif-containing proteins to the DNA sliding clamp by Proliferating cell nuclear antigen (PCNA) [72, 73] (Fig. 1e), the recruitment of SxIP motif-containing proteins to microtubule plus-end binding proteins [74], or the recruitment of $\mathrm{LxCxE}$ motif-containing proteins to E2Fregulated promoters by Retinoblastoma-associated protein (Rb) [75].

Thus, the evolutionary properties of motifs simplify access to many, widely relevant functionalities and facilitate the construction of diverse functional assemblies 


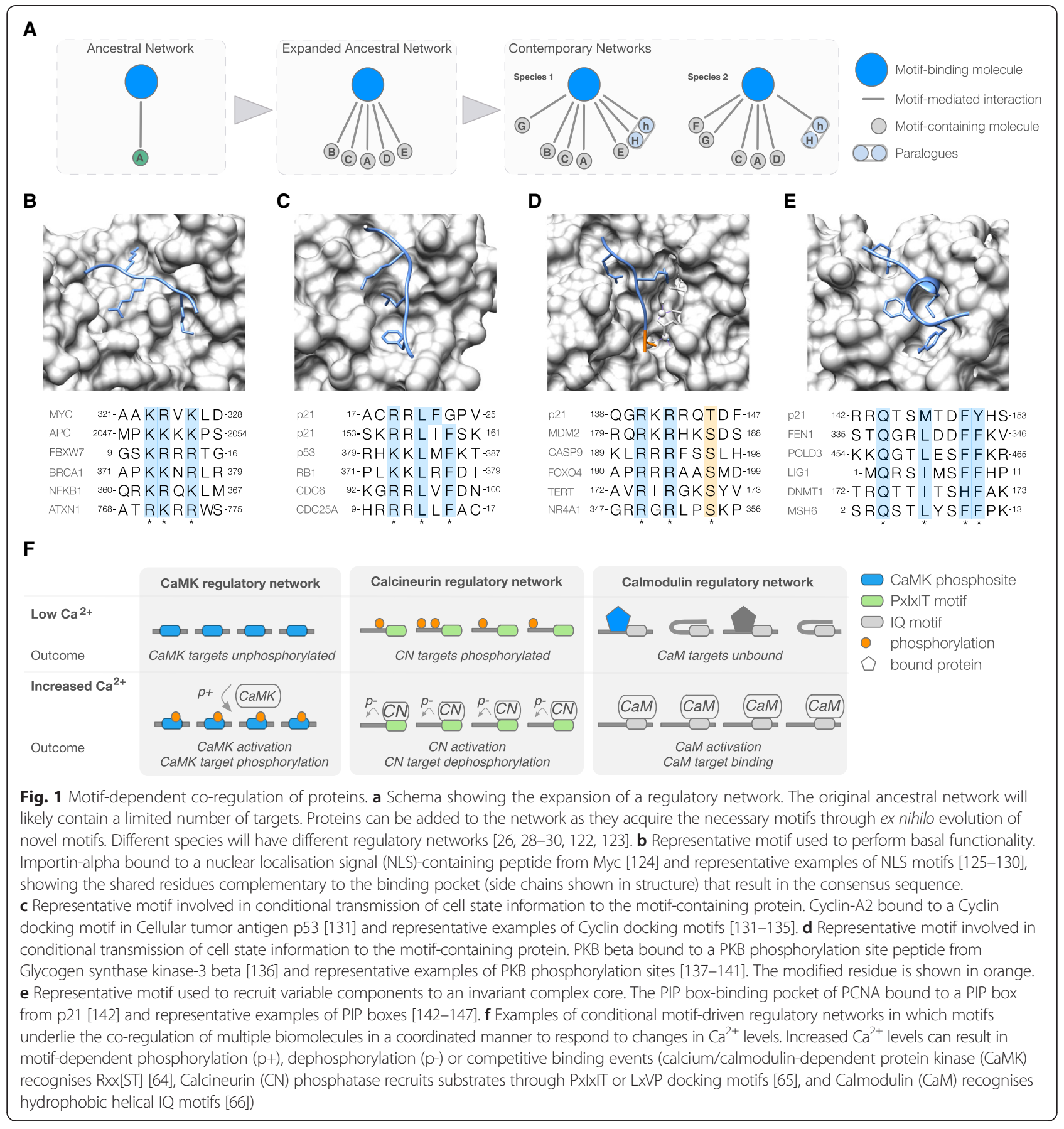

around a constant complex core. The higher eukaryotic cell contains innumerable co-regulated networks of biomolecules that are connected by motifs. Experimental analyses of these networks should consider that the modulation of a single motif could have effects across the network.

\section{Motif co-operativity}

Motifs are autonomous functional binding modules that can independently engage in an interaction. Many motifs can function in isolation, however, in many cases, a binding or modification event at one motif will affect binding to or modification of another motif, i.e. motifs generally act co-operatively. Multiple distinct motifmediated binding and/or modification events can affect each other either positively or negatively to various degrees, i.e. they can induce, promote, inhibit or completely abrogate each other. The cell extensively exploits motif co-operativity and to date, many experimentally validated cases of co-operative binding of motifs have 
been described [19]. Co-operative binding can serve to increase the specificity of an interaction, to increase the affinity of an interaction, and/or to integrate cell state information, as will be described in the following paragraphs $[1,4]$.

A common strategy in motif interactions is the cooperative binding of multiple motifs and motif-binding domains, which in isolation are somewhat promiscuous, to mediate highly specific interactions. Motif-binding domains or motifs can co-operate at an intermolecular level, through multimerisation of the motif-binding or motifcontaining partners [76] (Fig. 2a), or at an intramolecular level, for example many motif-binding domains (e.g. zinc fingers for DNA motifs, RNA recognition motifs (RRM) for RNA motifs, and SH2, SH3 and PDZ domains for SLiMs) occur as tandem arrays to increase binding specificity [77-79] (Fig. 2b). In proteins, multiple pockets on the same globular domain can also function co-operatively [80] (Fig. 2c). These mechanisms, in addition to temporal and spatial separation of biomolecules [81], permit highfidelity recognition of biologically relevant binding partners despite the large number of sequences that are complementary to the specificity of a single motif-binding module [4]. The same mechanisms also allow the intrinsically weak affinities of a single motif (a particular feature of SLiMs, which mediate interactions with affinities that are generally in the $1-10 \mu \mathrm{M}$ range) to be increased by binding multivalently with high avidity. The binding strength of these interactions can increase by orders of magnitude while the system retains much of the dynamism of the constituent parts [82, 83]. For instance, robust localisation of Amphiphysin 1 to the periphery of assembling clathrin lattices depends on two distinct motifs that bind to two independent sites on the N-terminal beta-propeller domain of clathrin, which increases the affinity and specificity of the interaction [84]. Similarly, higher order use of cooperative avidity-driven binding mechanisms also allows motifs to recruit, organise and stabilise large dynamic

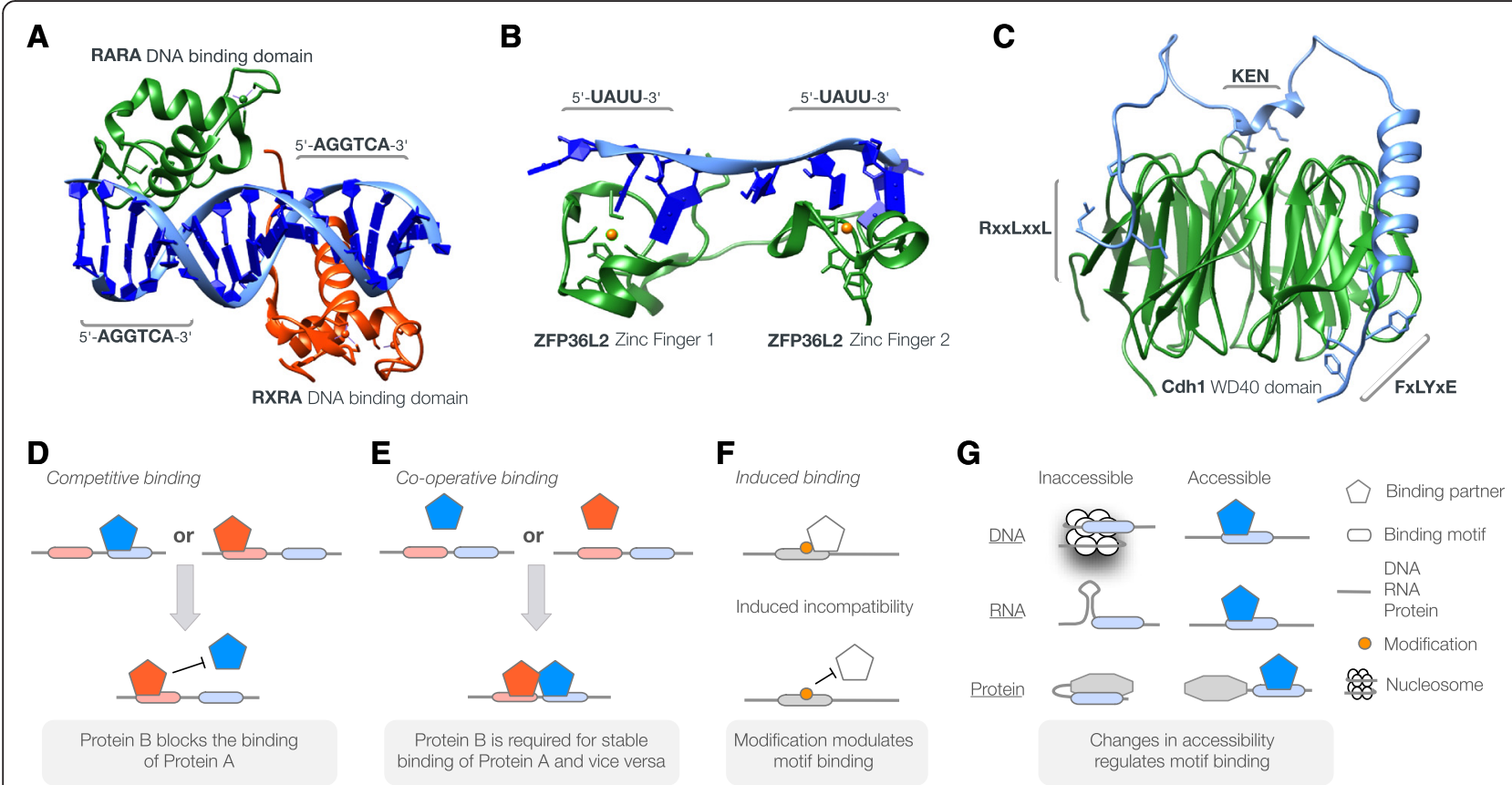

Fig. 2 Examples of co-operative interactions mediated by DNA, RNA and protein motifs. a DNA motif specificity through multivalent interactions with motif-binding domains in multimeric complexes. Structure of Retinoic acid receptor alpha (RARA) (green) and Retinoic acid receptor RXR-alpha (RXRA) (red) heterodimer bound to a retinoic acid response element (5'-AGGTCAAAGGTCA-3') (blue) [107]. Each protein binds to a 6-mer "half-site" (5'-AGGTCA-3') giving the complex specificity for a 12-mer motif. b RNA motif specificity through multivalent interactions with tandem arrays of motif-binding domains. Structure of the tandem Zinc Fingers of Zinc finger protein 36, C3H1 type-like 2 (ZFP36L2) (green) bound to an RNA class II AU-rich element (ARE) (5'-UUAUUUAUU-3') (blue). Each Zinc Finger recognises 4 nucleotides of RNA, allowing the tandem domains to recognise an 8-mer motif [78]. c Protein motif specificity through multivalency. Structure of yeast APC/C-Cdh1 modulator 1 (Acm1) (blue) bound to APC/C activator protein Cdh1 (green) showing the 3 binding pockets for the D box (RxxLxxL), KEN box (KEN) and ABBA motif (FxLYxE) on the WD40 repeat of Cdh1 [80]. $\mathbf{d}$ Example of competitive motif-mediated binding involving two motifs. Binding of a single biomolecule/complex to a motif is sufficient to perform the biological function; however, when a second biomolecule is present, the function facilitated by the first site is inhibited [19, 87, 148-150]. e Schematic example of co-operative motif-mediated interactions involving two motifs. In the example, binding of a single interface is insufficient to elicit the functional outcome of binding. Once the second motif-binding interface associates, the trimeric complex can bind with sufficient affinity/avidity to elicit the biological outcome. f Modification on or near a regulatory motif can modulate the motif either positively [89, 151-154] or negatively [18, 19, 94]. $g$ Motif accessibility is required for binding partner recruitment and, consequently, is often utilised as a step of regulation $[18,19,99,100,155]$ 
multimeric complexes such as those that assemble at DNA regulatory element-rich gene promoters [24] or on SLiMrich scaffolding proteins $[1,85]$.

In addition to directing multi-partite interactions with high specificity and avidity, motif co-operativity also plays a fundamental role in cellular decision-making. A single motif instance is not intrinsically conditional. However, through regulation of the local abundance of the motif-binding partner and/or through co-operative or competitive use of multiple motifs, combinatorial decision-making is possible [1]. A binding or modification event at one motif can modulate the occupancy state of another motif, thus changing the functionality of the second motif. Accordingly, the co-operative nature of their interactions provides motifs the means to integrate cell state information from multiple inputs and propagate regulatory decisions based on this information. Binding motifs can influence each other in different ways $[18,19]$. Overlapping or adjacent motifs can promote mutually exclusive, competitive interactions, allowing context-dependent assembly of functionally distinct complexes [86] (Fig. 2d). For instance, in Rb, the docking motif for the catalytic subunit of protein phosphatase 1 (PP1) and the cyclin docking motif that recruits cyclinCdk complexes overlap. While binding to PP1 results in dephosphorylation of $\mathrm{Rb}$, keeping it active as a repressor of E2F-dependent transcription, binding to cyclin-Cdk results in phosphorylation and inactivation of $\mathrm{Rb}$, thus promoting cell cycle progression [87]. Alternatively, adjacent motifs can co-operate positively, facilitating the integration of signals encoded in the presence of their different binding partners [88] (Fig. 2e). Such cooperativity occurs during assembly of the $\mathrm{T}$ cell signalling complex on the Linker for activation of T-cells family member 1 (LAT) scaffold protein, which contains multiple SH2 domain-binding motifs that, upon phosphorylation, recruit a variety of signalling proteins through their respective $\mathrm{SH} 2$ domains to build a functional signalling complex [88]. Another key mechanism for cell state dependent decision-making is mediated by modulation of the intrinsic affinity and/or specificity of a motif by modification of one or more overlapping or neighbouring modification motifs $[89,90]$. The binding properties of a motif can be adjusted by the covalent attachment of a moiety (Fig. 2f), ranging from switching on intrinsically inactive motifs that require a specific modification in order to be active [91, 92] (for instance, Plk1-catalysed phosphorylation of two serine residues in the beta-TrCP-binding degron in Claspin is required for its interaction with beta- $\operatorname{TrCP}$ and the associated ubiquitin ligase complex, resulting in ubiquitylation and subsequent proteasomal degradation of Claspin, a process involved in termination of the DNA replication checkpoint [93]), disrupting an interaction [94, 95] (such as binding of the USP7-docking motif in Mdm4 to the deubiquitylating enzyme USP7, which is inhibited by phosphorylation of a serine residue adjacent to the motif by ATM kinase to promote Mdm4 destabilisation during DNA damage response [96]) or changing the specificity of a binding region from one binding partner to another [97] (for example, phosphorylation of a tyrosine residue in a PTB domain-binding motif in the Integrin beta-3 tail negatively regulates integrin activation by switching the specificity of the binding region from Talin to Dok1 [98]). The binding properties of a motif or a motifbinding domain can also be modulated indirectly by allosteric effects, resulting from modification or effector association/dissociation at a site that is distinct from the actual interaction interface [99-101] (Fig. 2g). A well characterised example of allosteric regulation of SLiMmediated interactions involves ligand-induced activation of the Wiskott-Aldrich syndrome protein (WAS), where binding of Cdc42 relieves a motif-mediated autoinhibitory interaction in WAS, resulting in activation of the protein [102].

On a molecular level, some motifs will function independently, whereas others will be contained in multimotif co-operative interfaces. This raises the question whether there exist pairings of motifs that can cooperate and others that cannot? Or is the requirements of the system the only limit on the observed co-operative motif pairings? The mechanisms driving the evolution of motif co-operativity is an open question and only a handful of examples of a co-operative motif being added to a preexistant motif interface have been fully characterized $[25,39]$. However, given the simplicity of motif acquisition, most motif pairings will have been tested by evolution. It is likely that unobserved pairings are of limited biological utility and consequently are not retained. It is clear that many commonly observed co-operative motif pairings reflect the available motif-binding pockets in the binding partner, for example, docking motifs and modification sites for the same PTM enzyme will often occur in the same protein, increasing the efficiency and specificity of modification [78, 80, 103-107]. Furthermore, intuitively, motifs with related functionality will be more likely to co-operate (i.e. cell cycle kinase modification motifs often regulate adjacent cell cycle-related interaction motifs such as the mitotic degron motifs [108-111]). Depending on the spatial organisation and flexibility of the motif-binding partner, constraints may be placed on the minimum or maximum inter-motif distance and the ordering of the motifs; such constraints have been observed for the APC/C and the Cdk/Cyclin/ Cks1 complex [80, 112-114].

In summary, the unique evolutionary and binding attributes of motifs in DNA, RNA and proteins facilitate two highly exploited mechanisms: (i) the co-operative 
use of multiple independent low-affinity and lowspecificity binding sites to allow highly specific assembly of dynamic, meta-stable complexes, and (ii) the cooperative integration of information in conditional decision-making interfaces. Consequently, the function of many motifs cannot be fully determined if the analysis is restricted to discrete instances.

\section{Motif-driven regulatory programs}

Evolution rarely creates completely new molecular functions, and more readily works with existing tools to produce novelty-as François Jacob stated, "Evolution is a tinkerer, not an inventor" [115]. On the molecular level, this is clearly evident as the modular nature of biomolecules permits evolution to reuse useful modules in novel combinations to produce distinct biological outcomes [116].

The cell has a vast repertoire of DNA, RNA and protein motifs that carry out a wide range of functions (Table 1). Addition of these motifs can have a marked effect on a biomolecule; for example, on the protein level, addition of modules can modify the subcellular localisation, stability, modification state and interactome of a protein, hence affecting its activity and function (Fig. 3a-b). The small footprint of motifs permits the addition of a module to add novel functionality without disrupting the ancestral functionality $[25,39]$. Consequently, biomolecules can contain multiple motifs $[117,118]$ (Table 2). As discussed in the previous section, each motif can co-operate with additional motifs and together these simple components can exhibit complex behaviour due to their conditional connectivity. The set of motifs in a biomolecule encodes a regulatory program that defines the logic of its decisionmaking circuitry: controlling under what conditions and to what degree transcription proceeds; the processing, location, stability and translation of RNA; and the localisation, stability, modification state and interactome of a protein. The regulatory program also defines how the biomolecule integrates the available information encoded in its own local abundance, the local abundance of its binding partners, binding site occupancy and modification state, to produce a functional outcome. Different sets of modules, or the same set of modules with distinct conditional connectivity, can respond differently to the same changes in cell state, allowing each biomolecule to build unique regulatory programs (Fig. $3 \mathrm{c}-\mathrm{d}$ ).

Ultimately, tens to hundreds of modules in DNA, RNA and proteins, many of them motifs, regulate the life cycle of every gene product on the transcriptional, post-transcriptional and post-translational levels from transcription to degradation (Table 2, Fig. 4) [119].

\section{Conclusions}

Biomolecules are robustly regulated from their transcription to their destruction to generate high fidelity control

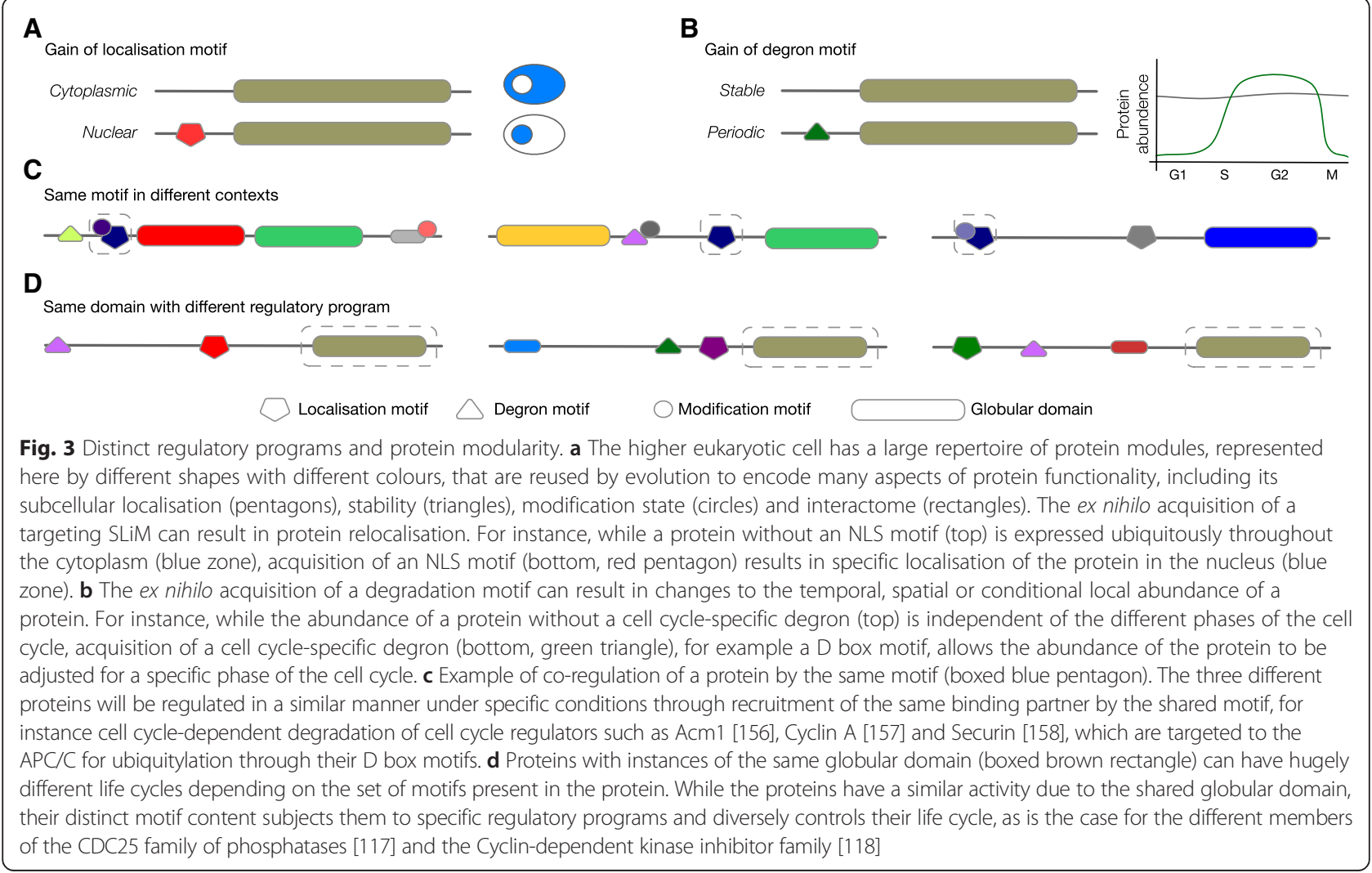


Table 2 Representative examples of motifs modulating the abundance and function of Cyclin-dependent kinase inhibitor 1 ( $p 21$ )

\begin{tabular}{|c|c|c|c|}
\hline Motif & Motif sequence & Binding domain/partner & Function \\
\hline \multicolumn{4}{|l|}{ Protein short linear motifs } \\
\hline Cyclin docking motif [187] & ${ }_{19} \mathrm{RRLF}_{22}$ & Cyclin fold of G1/S-specific cyclin-E1 & $\begin{array}{l}\text { Inhibition of Cyclin E-Cdk2 catalytic activity and sub- } \\
\text { strate recruitment }\end{array}$ \\
\hline Cyclin docking motif [188] & ${ }_{155} \mathrm{RRLIF}_{159}$ & Cyclin fold of G1/S-specific cyclin-E1 & $\begin{array}{l}\text { Docking to the Cyclin E subunit of the Cyclin E-Cdk2 } \\
\text { kinase complex, which results in phosphorylation of p21 } \\
\text { at S130 by Cdk2 and subsequent destabilisation of p21 }\end{array}$ \\
\hline PCNA-binding PIP box $[86,186]$ & ${ }_{144} \mathrm{QTSMTDFYHS}_{153}$ & Proliferating cell nuclear antigen & $\begin{array}{l}\text { Inhibition of the DNA polymerase delta processivity } \\
\text { factor PCNA, resulting in G1 and G2 cell cycle arrest }\end{array}$ \\
\hline Nuclear localisation signal (NLS) [189] & ${ }_{142}$ RRQTSMTDFYHSKRRLI $_{158}$ & Armadillo domain of Importin-alpha & $\begin{array}{l}\text { Translocation of p } 21 \text { from the cytosol to the nucleus } \\
\text { where it exerts it's effects on cell proliferation }\end{array}$ \\
\hline APC/C-binding D Box degron [185] & ${ }_{86} \mathrm{RDELGGGR}_{93}$ & $\begin{array}{l}\text { WD40 repeat of Cell division cycle protein } \\
20 \text { homolog }\end{array}$ & $\begin{array}{l}\text { Ubiquitylation of p21, thereby targeting the protein for } \\
\text { proteasomal degradation during prometaphase }\end{array}$ \\
\hline PIP degron motif [183] & ${ }_{145}$TSMTDFYHSKRRL $_{157}$ & WD40 repeat of Denticleless protein homolog & $\begin{array}{l}\text { PCNA- and ubiquitin-dependent proteasomal degradation } \\
\text { of p21 in S phase and after UV irradiation }\end{array}$ \\
\hline Cdk2 phosphosite [193] & ${ }_{130}(\mathrm{~S}) \mathrm{P}_{131}$ & Kinase domain of Cyclin-dependent kinase 2 & $\begin{array}{l}\text { Targets p21 for ubiquitylation and subsequent } \\
\text { proteasomal degradation }\end{array}$ \\
\hline PKB phosphosite [190] & ${ }_{140} \mathrm{RKRRQ}(\mathrm{T})_{145}$ & Kinase domain of Protein kinase B (PKB) & $\begin{array}{l}\text { Results in cytoplasmic localisation of p21, prevents } \\
\text { complex formation with PCNA, and decreases the } \\
\text { inhibitory effect on Cyclin-Cdk complexes }\end{array}$ \\
\hline NDR phosphosite [192] & ${ }_{141} \mathrm{KRRQT}(\mathrm{S})_{146}$ & $\begin{array}{l}\text { Kinase domain of nuclear-Dbf2-related (NDR) } \\
\text { kinases }\end{array}$ & Destabilisation of p21 protein to control G1/S progression \\
\hline \multicolumn{4}{|l|}{ RNA motifs } \\
\hline miRNA [119] & $\begin{array}{l}\text { miRNA seed region (AAAGUGC) } \\
\text { complementary sites within the } 3^{\prime}-U T R\end{array}$ & miRNA miR-17,20a, 20b, 93, 106a, and 106b & Down-regulation of p21 expression \\
\hline HuD binding site $[177,220]$ & ${ }_{688} U_{U} \cup U C U U_{695}$ & RRM domain of ELAV-like protein 4 & Increased stability of p21 mRNA \\
\hline HuR binding site $[178,220]$ & AU-rich elements within nt 751-850 & RRM domain of ELAV-like protein 1 & Increased stability of p21 mRNA \\
\hline RNPC1 binding site $[179,220]$ & AU-rich elements within nt 621-750 & RRM domain of RNA-binding protein 38 & Increased stability of p21 mRNA \\
\hline Msi-1-binding site [180] & $\begin{array}{l}{ }_{1819} \mathrm{GUAGU}_{1823} \text { (on a loop portion of a } \\
\text { stem-loop-stem structure) }\end{array}$ & $\begin{array}{l}\text { RRM domain of RNA-binding protein Musashi } \\
\text { homolog } 1\end{array}$ & $\begin{array}{l}\text { Inhibition of p21 mRNA translation to regulate } \\
\text { progenitor maintenance }\end{array}$ \\
\hline GC-rich sequence [148] & within nt 37-59 & RRM domain of CUGBP Elav-like family member 1 & Increased translation of p21 mRNA \\
\hline GC-rich stem-loop structure [148] & within nt 37-59 & Calreticulin & $\begin{array}{l}\text { Blocks translation of p21 mRNA via stabilisation of a } \\
\text { stem-loop structure within the } 5^{\prime} \text { region }\end{array}$ \\
\hline CU-rich sequence [181] & CCANNCC within the $3^{\prime}-U T R$ & $\begin{array}{l}\mathrm{KH} \text { domain of Heterogeneous nuclear } \\
\text { ribonucleoprotein } \mathrm{K}\end{array}$ & Repression of p21 mRNA translation \\
\hline \multicolumn{4}{|l|}{ DNA regulatory elements } \\
\hline p53-responsive element $[159,160]$ & $\begin{array}{l}\text { GAACATGTCCCAACATGTT at }-2233 \text { and } \\
\text { GAAGAAGACTGGGCATGTCT at }-1351\end{array}$ & Cellular tumor antigen p53 & $\begin{array}{l}\text { p53-mediated up-regulation of p21 gene transcription } \\
\text { in response to stress signals such as DNA damage }\end{array}$ \\
\hline E-box motif [161] & CAGCTG at $-420,-163,-20$ and -5 & Helix-Loop-Helix of Transcription factor AP-4 & $\begin{array}{l}\text { AP-4-dependent repression of p21 gene transcription in } \\
\text { response to mitogenic signals }\end{array}$ \\
\hline
\end{tabular}


Table 2 Representative examples of motifs modulating the abundance and function of Cyclin-dependent kinase inhibitor 1 (p21) (Continued)

\begin{tabular}{|c|c|c|c|}
\hline Retinoid X response element (RXRE) [162] & $\begin{array}{l}\text { AGGTCAGGGGTGT at }-1198 \text { and } \\
\text { GAGGCAAAGGTGA at }-1221\end{array}$ & zf-C4 zinc finger of Retinoic acid receptor RXR-alpha & $\begin{array}{l}\text { RXR ligand-dependent induction of p21 gene expression } \\
\text { by RXR-alpha }\end{array}$ \\
\hline Retinoid acid response element (RARE) [163] & AGGTGAAGTCCAGGGGA at -1212 & $\begin{array}{l}\text { zf-C4 zinc finger of Retinoic acid receptor alpha } \\
\text { (RAR-alpha) }\end{array}$ & $\begin{array}{l}\text { Retinoic acid-dependent induction of p21 gene expression } \\
\text { by RAR-alpha }\end{array}$ \\
\hline Vitamin D response element (VDRE) [164] & AGGGAGATTGGTTCA at -770 & zf-C4 zinc finger of Vitamin D3 receptor & $\begin{array}{l}\text { 1,25-dihydroxyvitamin D3-dependent induction of p21 } \\
\text { gene expression by Vitamin D3 receptor }\end{array}$ \\
\hline CDX binding site [167] & Three TTTAT within -471 to -434 & Homeobox domain of Homeobox protein CDX-2 & Activation of p21 gene transcription by CDX-2 \\
\hline T-element [168] & $\begin{array}{l}\text { AGGTGTGA close to the transcription } \\
\text { start site (TSS) }\end{array}$ & T-box of T-box transcription factor TBX2 & Repression of the p21 gene promoter by TBX2 \\
\hline STAT binding element $[165,166]$ & $\begin{array}{l}\text { TTCCCGGAA at }-647, \text { TTCTGAGAAA } \\
\text { at }-2541 \text { and CTTCTTGGAAAT at }-4183\end{array}$ & $\begin{array}{l}\text { STAT fold of Signal transducer and activator } \\
\text { of transcription (STAT) proteins STAT1/STAT3/STAT5 }\end{array}$ & $\begin{array}{l}\text { STAT-dependent activation of p21 gene expression in } \\
\text { response to several cytokines }\end{array}$ \\
\hline NF-IL6 site [169] & $\begin{array}{l}\text { GTACTTAAGAAATATTGAA at } \\
\text { approximately }-1900\end{array}$ & $\begin{array}{l}\text { bZIP domain of CCAAT/enhancer-binding protein } \\
\text { beta }\end{array}$ & $\begin{array}{l}\text { Induction of p21 gene expression by CCAAT/enhancer- } \\
\text { binding protein beta }\end{array}$ \\
\hline Sp1 binding site [170-173] & $\begin{array}{l}6 \text { GC-rich Sp1-binding sites between }-120 \\
\text { and TSS }\end{array}$ & $\mathrm{C} 2 \mathrm{H} 2$ zinc finger of Transcription factor Sp1/Sp3 & Sp1/Sp3-dependent induction of p21 gene expression \\
\hline AP2 binding site [174] & GCGGTGGGC at -103 & Transcription factor AP-2-alpha & $\begin{array}{l}\text { Induction of p21 transcription and growth arrest by AP- } \\
\text { 2-alpha }\end{array}$ \\
\hline E2F binding site [175] & $\begin{array}{l}\text { CTCCGCGC at }-155 \text { and CGCGC at }-103 \text {, } \\
-89 \text { and }-36\end{array}$ & Winged-Helix of Transcription factor E2F1 & Activation of the p21 gene at the G1/S boundary by E2F1 \\
\hline Forkhead binding site [176] & TGTGTGC at $+2003^{\prime}$ of TSS & Forkhead domain of Forkhead box protein P3 & Induction of p21 transcription by Forkhead box protein P3 \\
\hline
\end{tabular}




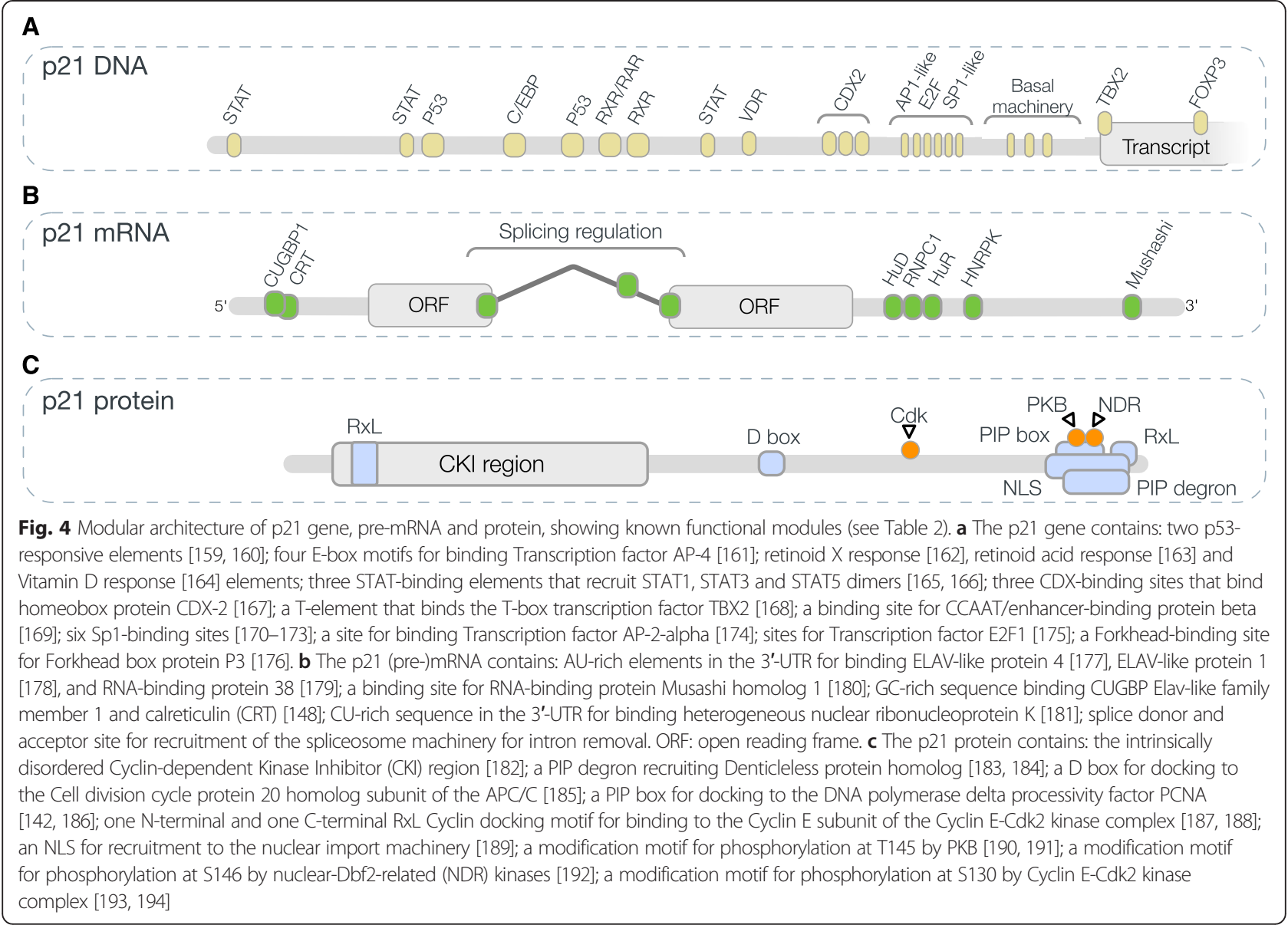

of cell physiology. An emerging concept in biology is that compact functional modules recognised by DNAbinding, RNA-binding and SLiM-binding biomolecules control much of the conditional decision-making in a cell $[18,120,121]$. The three major classes of biomolecules, DNA, RNA and proteins, extensively utilise short sequence motifs to determine the various aspects of their regulatory functionality and to conditionally recruit effectors based on the current cell state. Proliferation of these motifs facilitates biomolecule co-regulation and increases the complexity of cell regulation by expanding existing networks, thereby increasing the density of network wiring without any requirement to add new molecules to the proteome.

The discovery of the complete set of motifs is vital to our understanding of cell regulation. However, motifs co-operate and compete to encode the logic of decisionmaking and together, co-regulation and co-operativity produce intricate biological outcomes from simple motifs, generating the complicated regulation that underlies higher eukaryotic cell physiology. Consequently, to truly appreciate the regulatory program of a biomolecule, we cannot solely determine the repertoire of motifs, we must also establish the conditional connectivity between motifs. Thus, the regulatory segments of genes, the $5^{\prime}-$ UTRs, 3'-UTRs and introns of (pre-)mRNAs, and the intrinsically disordered regions of proteins should be seen as functionally analogous regions, and the DNA regulatory elements, RNA motifs and SLiMs contained within these regions should be considered the cornerstones of regulation in complex organisms, for without them, the observed level of regulatory complexity would not be achievable.

\section{Abbreviations}

SLiMs: Short linear motifs; miRNA: microRNA; HREs: Hypoxia response elements; IREs: Iron-responsive elements; UTRs: Untranslated regions; APC/ C: Anaphase-promoting complex/Cyclosome; RRM: RNA recognition motifs; ER: Endoplasmatic reticulum; NES: Nuclear export signal; PKB: Protein kinase B; NLS: Nuclear localisation signal.

\section{Competing interests}

The authors declare that they have no competing interests.

\section{Authors' contributions}

NED conceived the manuscript. NED and KVR wrote the manuscript. All authors read and approved the final manuscript. 


\section{Acknowledgements}

We apologise to all colleagues whose work could not be cited here owing to space restrictions. NED is supported by an SFI Starting Investigator Research Grant (13/SIRG/2193). We thank Holger Dinkel, Richard Edwards, Toby Gibson and Aino Järvelin for fruitful discussions and critically reading the manuscript.

\section{Author details}

${ }^{1}$ Structural and Computational Biology Unit, European Molecular Biology

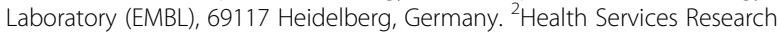
Unit, Operational Direction Public Health and Surveillance, Scientific Institute of Public Health (WIV-ISP), 1050 Brussels, Belgium. ${ }^{3}$ Conway Institute of Biomolecular and Biomedical Sciences, University College Dublin, Dublin 4, Ireland.

Received: 7 July 2015 Accepted: 24 November 2015 Published online: 01 December 2015

\section{References}

1. Van Roey K, Uyar B, Weatheritt RJ, Dinkel H, Seiler M, Budd A, et al. Short linear motifs: ubiquitous and functionally diverse protein interaction modules directing cell regulation. Chem Rev. 2014;114(13):6733-78.

2. Gardner PP, Eldai H. Annotating RNA motifs in sequences and alignments. Nucleic Acids Res. 2015:43(2):691-8.

3. Maston GA, Evans SK, Green MR. Transcriptional regulatory elements in the human genome. Annu Rev Genomics Hum Genet. 2006;7:29-59.

4. Davey NE, Van Roey K, Weatheritt RJ, Toedt G, Uyar B, Altenberg B, et al. Attributes of short linear motifs. Mol Biosyst. 2012;8(1):268-81.

5. Weirauch MT, Yang A, Albu M, Cote AG, Montenegro-Montero A, Drewe P, et al. Determination and inference of eukaryotic transcription factor sequence specificity. Cell. 2014;158(6):1431-43.

6. Yusuf D, Butland SL, Swanson MI, Bolotin E, Ticoll A, Cheung WA, et al. The transcription factor encyclopedia. Genome Biol. 2012;13(3):R24.

7. Ray D, Kazan H, Cook KB, Weirauch MT, Najafabadi HS, Li X, et al. A compendium of RNA-binding motifs for decoding gene regulation. Nature. 2013;499(7457):172-7.

8. Dinkel H, Van Roey K, Michael S, Davey NE, Weatheritt RJ, Born D, et al. The eukaryotic linear motif resource ELM: 10 years and counting. Nucleic Acids Res. 2014;42(Database issue):D259-66.

9. Kim Y, Geiger JH, Hahn S, Sigler PB. Crystal structure of a yeast TBP/TATAbox complex. Nature. 1993;365(6446):512-20.

10. Miller M, Shuman JD, Sebastian T, Dauter Z, Johnson PF. Structural basis for DNA recognition by the basic region leucine zipper transcription factor CCAAT/enhancer-binding protein alpha. J Biol Chem. 2003;278(17):15178-84.

11. Holwerda SJ, de Laat W. CTCF: the protein, the binding partners, the binding sites and their chromatin loops. Philos Trans R Soc Lond B Biol Sci. 2013;368(1620):20120369

12. Kim YC, Grable JC, Love R, Greene PJ, Rosenberg JM. Refinement of Eco RI endonuclease crystal structure: a revised protein chain tracing. Science (New York, NY). 1990;249(4974):1307-9.

13. Barreau C, Paillard L, Osborne HB. AU-rich elements and associated factors: are there unifying principles? Nucleic Acids Res. 2005;33(22):7138-50.

14. Kondo Y, Oubridge C, van Roon AM, Nagai K. Crystal structure of human U1 snRNP, a small nuclear ribonucleoprotein particle, reveals the mechanism of 5' splice site recognition. Elife. 2015;4. doi: 10.7554/eLife.04986.

15. Beaudoing E, Freier S, Wyatt JR, Claverie JM, Gautheret D. Patterns of variant polyadenylation signal usage in human genes. Genome Res. 2000;10(7):1001-10.

16. Wang ET, Cody NA, Jog S, Biancolella M, Wang TT, Treacy DJ, et al. Transcriptome-wide regulation of pre-mRNA splicing and mRNA localization by muscleblind proteins. Cell. 2012;150(4):710-24

17. Le MT, Shyh-Chang N, Khaw SL, Chin L, Teh C, Tay J, et al. Conserved regulation of p53 network dosage by microRNA-125b occurs through evolving miRNA-target gene pairs. PLoS Genet. 2011;7(9):e1002242.

18. Van Roey K, Gibson TJ, Davey NE. Motif switches: decision-making in cell regulation. Curr Opin Struct Biol. 2012;22(3):378-85.

19. Van Roey K, Dinkel H, Weatheritt RJ, Gibson TJ, Davey NE. The switches. ELM resource: a compendium of conditional regulatory interaction interfaces. Sci Signal. 2013:6(269):rs7.

20. Hogan DJ, Riordan DP, Gerber AP, Herschlag D, Brown PO. Diverse RNAbinding proteins interact with functionally related sets of RNAs, suggesting an extensive regulatory system. PLoS Biol. 2008;6(10):e255.
21. Dreyfuss G, Kim VN, Kataoka N. Messenger-RNA-binding proteins and the messages they carry. Nat Rev Mol Cell Biol. 2002;3(3):195-205.

22. Tompa P, Davey NE, Gibson TJ, Babu MM. A million peptide motifs for the molecular biologist. Mol Cell. 2014;55(2):161-9.

23. Fuxreiter M, Tompa P, Simon I, Uversky VN, Hansen JC, Asturias FJ. Malleable machines take shape in eukaryotic transcriptional regulation. Nat Chem Biol. 2008;4(12):728-37.

24. Panne D, Maniatis T, Harrison SC. An atomic model of the interferon-beta enhanceosome. Cell. 2007;129(6):1111-23.

25. Gogl G, Schneider KD, Yeh BJ, Alam N, Nguyen Ba AN, Moses AM, et al. The structure of an NDR/LATS Kinase-Mob complex reveals a novel kinase-coactivator system and substrate docking mechanism. PLoS Biol. 2015;13(5):e1002146.

26. Nguyen Ba AN, Strome B, Hua JJ, Desmond J, Gagnon-Arsenault I, Weiss EL, et al. Detecting functional divergence after gene duplication through evolutionary changes in posttranslational regulatory sequences. PLoS Comput Biol. 2014;10(12):e1003977.

27. Goldman A, Roy J, Bodenmiller B, Wanka S, Landry CR, Aebersold R, et al. The calcineurin signaling network evolves via conserved kinase-phosphatase modules that transcend substrate identity. Mol Cell. 2014;55(3):422-35.

28. Xin X, Gfeller D, Cheng J, Tonikian R, Sun L, Guo A, et al. SH3 interactome conserves general function over specific form. Mol Syst Biol. 2013;9:652.

29. Sun MG, Sikora M, Costanzo M, Boone C, Kim PM. Network evolution: rewiring and signatures of conservation in signaling. PLoS Comput Biol. 2012;8(3):e1002411.

30. Kim J, Kim I, Yang JS, Shin YE, Hwang J, Park S, et al. Rewiring of PDZ domain-ligand interaction network contributed to eukaryotic evolution. PLoS Genet. 2012;8(2):e1002510.

31. Wray GA, Hahn MW, Abouheif E, Balhoff JP, Pizer M, Rockman MV, et al. The evolution of transcriptional regulation in eukaryotes. Mol Biol Evol. 2003;20(9):1377-419.

32. Villar D, Flicek P, Odom DT. Evolution of transcription factor binding in metazoans - mechanisms and functional implications. Nat Rev Genet. 2014;15(4):221-33.

33. Wittkopp PJ, Kalay G. Cis-regulatory elements: molecular mechanisms and evolutionary processes underlying divergence. Nat Rev Genet. 2012;13(1):59-69.

34. Ballester B, Medina-Rivera A, Schmidt D, Gonzalez-Porta M, Carlucci M, Chen $X$, et al. Multi-species, multi-transcription factor binding highlights conserved control of tissue-specific biological pathways. Elife. 2014;3:e02626.

35. Neduva $V$, Russell RB. Linear motifs: evolutionary interaction switches. FEBS Lett. 2005;579(15):3342-5.

36. Vogel C, Bashton M, Kerrison ND, Chothia C, Teichmann SA. Structure, function and evolution of multidomain proteins. Curr Opin Struct Biol. 2004;14(2):208-16.

37. Nakamura T, Alder H, Gu Y, Prasad R, Canaani O, Kamada N, et al. Genes on chromosomes 4, 9, and 19 involved in $11 \mathrm{q} 23$ abnormalities in acute leukemia share sequence homology and/or common motifs. Proc Natl Acad Sci U S A. 1993;90(10):4631-5.

38. Heffer A, Shultz JW, Pick L. Surprising flexibility in a conserved Hox transcription factor over 550 million years of evolution. Proc Natl Acad Sci U S A. 2010;107(42):18040-5.

39. Moses AM, Liku ME, Li JJ, Durbin R. Regulatory evolution in proteins by turnover and lineage-specific changes of cyclin-dependent kinase consensus sites. Proc Natl Acad Sci U S A. 2007;104(45):17713-8.

40. Moses AM, Landry CR. Moving from transcriptional to phospho-evolution: generalizing regulatory evolution? Trends Genet. 2010;26(11):462-7.

41. Holt LJ, Tuch BB, Villen J, Johnson AD, Gygi SP, Morgan DO. Global analysis of Cdk1 substrate phosphorylation sites provides insights into evolution. Science (New York, NY). 2009:325(5948):1682-6.

42. Cordeddu V, Di Schiavi E, Pennacchio LA, Ma'ayan A, Sarkozy A, Fodale V, et al. Mutation of SHOC2 promotes aberrant protein $\mathrm{N}$-myristoylation and causes Noonan-like syndrome with loose anagen hair. Nat Genet. 2009; 41(9):1022-6.

43. Vaquerizas JM, Kummerfeld SK, Teichmann SA, Luscombe NM. A census of human transcription factors: function, expression and evolution. Nat Rev Genet. 2009;10(4):252-63.

44. Castello A, Fischer B, Eichelbaum K, Horos R, Beckmann BM, Strein C, et al. Insights into RNA biology from an atlas of mammalian mRNA-binding proteins. Cell. 2012;149(6):1393-406.

45. Vogel C, Chothia C. Protein family expansions and biological complexity. PLoS Comput Biol. 2006;2(5):e48.

46. Kozomara A, Griffiths-Jones S. miRBase: integrating microRNA annotation and deep-sequencing data. Nucleic Acids Res. 2011;39(Database issue):D152-7. 
47. Cook KB, Kazan H, Zuberi K, Morris Q, Hughes TR. RBPDB: a database of RNA-binding specificities. Nucleic Acids Res. 2011;39(Database issue):D301-8.

48. Nair R, Carter P, Rost B. NLSdb: database of nuclear localization signals. Nucleic Acids Res. 2003;31(1):397-9.

49. Matlin AJ, Clark F, Smith CW. Understanding alternative splicing: towards a cellular code. Nat Rev Mol Cell Biol. 2005;6(5):386-98.

50. Pentony MM, Jones DT. Modularity of intrinsic disorder in the human proteome. Proteins. 2010;78(1):212-21.

51. Fuxreiter $M$, Tompa $P$, Simon I. Local structural disorder imparts plasticity on linear motifs. Bioinformatics (Oxford, England). 2007;23(8):950-6.

52. Edwards RJ, Palopoli N. Computational prediction of short linear motifs from protein sequences. Methods Mol Biol. 2015;1268:89-141.

53. Blikstad C, Ivarsson Y. High-throughput methods for identification of protein-protein interactions involving short linear motifs. Cell Commun Signal. 2015;13(1):38.

54. Hahn MW, Wray GA. The g-value paradox. Evol Dev. 2002;4(2):73-5.

55. Xia K, Fu Z, Hou L, Han JD. Impacts of protein-protein interaction domains on organism and network complexity. Genome Res. 2008;18(9):1500-8.

56. Schad E, Tompa P, Hegyi $H$. The relationship between proteome size, structural disorder and organism complexity. Genome Biol. 2011;12(12):R120.

57. Miller WT. Tyrosine kinase signaling and the emergence of multicellularity. Biochim Biophys Acta. 2012;1823(6):1053-7.

58. de Laat W, Duboule D. Topology of mammalian developmental enhancers and their regulatory landscapes. Nature. 2013;502(7472):499-506.

59. Kaluz S, Kaluzova M, Stanbridge EJ. Regulation of gene expression by hypoxia: integration of the HIF-transduced hypoxic signal at the hypoxia-responsive element. Clin Chim Acta. 2008;395(1-2):6-13.

60. Wang J, Pantopoulos K. Regulation of cellular iron metabolism. Biochem J. 2011;434(3):365-81.

61. Primorac I, Musacchio A. Panta rhei: the APC/C at steady state. J Cell Biol. 2013;201(2):177-89.

62. Yang C, Bolotin E, Jiang T, Sladek FM, Martinez E. Prevalence of the initiator over the TATA box in human and yeast genes and identification of DNA motifs enriched in human TATA-less core promoters. Gene. 2007;389(1):52-65.

63. Crawford ED, Seaman JE, Barber 2nd AE, David DC, Babbitt PC, Burlingame $A L$, et al. Conservation of caspase substrates across metazoans suggests hierarchical importance of signaling pathways over specific targets and cleavage site motifs in apoptosis. Cell Death Differ. 2012;19(12):2040-8.

64. Hudmon A, Schulman H. Structure-function of the multifunctional Ca2+/calmodulin-dependent protein kinase II. Biochem J. 2002;364(Pt 3):593-611.

65. Roy J, Cyert MS. Cracking the phosphatase code: docking interactions determine substrate specificity. Sci Signal. 2009;2(100):re9.

66. Bahler M, Rhoads A. Calmodulin signaling via the IQ motif. FEBS Lett. 2002;513(1):107-13.

67. Harbour JW, Dean DC. The Rb/E2F pathway: expanding roles and emerging paradigms. Genes Dev. 2000;14(19):2393-409.

68. Pines J. Cubism and the cell cycle: the many faces of the APC/C. Nat Rev Mol Cell Biol. 2011;12(7):427-38.

69. Chen D, Farwell MA, Zhang B. MicroRNA as a new player in the cell cycle. J Cell Physiol. 2010;225(2):296-301.

70. Lakin ND, Jackson SP. Regulation of p53 in response to DNA damage. Oncogene. 1999;18(53):7644-55.

71. Shiloh Y, Ziv Y. The ATM protein kinase: regulating the cellular response to genotoxic stress, and more. Nat Rev Mol Cell Biol. 2013;14(4):197-210.

72. Warbrick E. PCNA binding through a conserved motif. Bioessays. 1998;20(3):195-9.

73. Mailand N, Gibbs-Seymour I, Bekker-Jensen S. Regulation of PCNA-protein interactions for genome stability. Nat Rev Mol Cell Biol. 2013;14(5):269-82.

74. Jiang K, Toedt G, Montenegro Gouveia S, Davey NE, Hua S, van der Vaart B, et al. A Proteome-wide screen for mammalian SxIP motif-containing microtubule plus-end tracking proteins. Curr Biol. 2012;22(19):1800-7.

75. Dick FA, Rubin SM. Molecular mechanisms underlying RB protein function. Nat Rev Mol Cell Biol. 2013;14(5):297-306.

76. Leid M, Kastner P, Lyons R, Nakshatri H, Saunders M, Zacharewski T, et al. Purification, cloning, and RXR identity of the HeLa cell factor with which RAR or TR heterodimerizes to bind target sequences efficiently. Cell. 1992;68(2):377-95.

77. Lam KN, van Bakel H, Cote AG, van der Ven A, Hughes TR. Sequence specificity is obtained from the majority of modular $\mathrm{C} 2 \mathrm{H} 2$ zinc-finger arrays. Nucleic Acids Res. 2011;39(11):4680-90.
78. Hudson BP, Martinez-Yamout MA, Dyson HJ, Wright PE. Recognition of the mRNA AU-rich element by the zinc finger domain of TIS11d. Nat Struct Mol Biol. 2004;11(3):257-64

79. Pawson T, Nash P. Protein-protein interactions define specificity in signal transduction. Genes Dev. 2000;14(9):1027-47.

80. He J, Chao WC, Zhang Z, Yang J, Cronin N, Barford D. Insights into degron recognition by APC/C coactivators from the structure of an Acm1-Cdh1 complex. Mol Cell. 2013;50(5):649-60.

81. Scott JD, Pawson T. Cell signaling in space and time: where proteins come together and when they're apart. Science (New York, NY). 2009;326(5957): 1220-4.

82. Bu JY, Shaw AS, Chan AC. Analysis of the interaction of ZAP-70 and syk protein-tyrosine kinases with the T-cell antigen receptor by plasmon resonance. Proc Natl Acad Sci U S A. 1995;92(11):5106-10.

83. Kostelecky B, Saurin AT, Purkiss A, Parker PJ, McDonald NQ. Recognition of an intra-chain tandem 14-3-3 binding site within PKCepsilon. EMBO Rep. 2009;10(9):983-9.

84. Miele AE, Watson PJ, Evans PR, Traub LM, Owen DJ. Two distinct interaction motifs in amphiphysin bind two independent sites on the clathrin terminal domain beta-propeller. Nat Struct Mol Biol. 2004;11(3):242-8.

85. Brownlie RJ, Zamoyska R. T cell receptor signalling networks: branched, diversified and bounded. Nat Rev Immunol. 2013;13(4):257-69.

86. Lee JH, Richter W, Namkung W, Kim KH, Kim E, Conti M, et al. Dynamic regulation of cystic fibrosis transmembrane conductance regulator by competitive interactions of molecular adaptors. J Biol Chem. 2007;282(14):10414-22.

87. Hirschi A, Cecchini M, Steinhardt RC, Schamber MR, Dick FA, Rubin SM. An overlapping kinase and phosphatase docking site regulates activity of the retinoblastoma protein. Nat Struct Mol Biol. 2010;17(9):1051-7.

88. Balagopalan L, Coussens NP, Sherman E, Samelson LE, Sommers CL. The LAT story: a tale of cooperativity, coordination, and choreography. Cold Spring Harb Perspect Biol. 2010;2(8):a005512.

89. Lee M, Kim B, Kim VN. Emerging roles of RNA modification: m(6)A and U-tail. Cell. 2014;158(5):980-7.

90. Akiva E, Friedlander G, Itzhaki Z, Margalit H. A dynamic view of domainmotif interactions. PLoS Comput Biol. 2012;8(1):e1002341.

91. Lassot I, Segeral E, Berlioz-Torrent C, Durand H, Groussin L, Hai T, et al. ATF4 degradation relies on a phosphorylation-dependent interaction with the SCF(betaTrCP) ubiquitin ligase. Mol Cell Biol. 2001;21(6):2192-202.

92. Ho KL, McNae IW, Schmiedeberg L, Klose RJ, Bird AP, Walkinshaw MD. MeCP2 binding to DNA depends upon hydration at methyl-CpG. Mol Cell. 2008;29(4):525-31.

93. Peschiaroli A, Dorrello NV, Guardavaccaro D, Venere M, Halazonetis T, Sherman $\mathrm{NE}$, et al. SCFbetaTrCP-mediated degradation of Claspin regulates recovery from the DNA replication checkpoint response. Mol Cell. 2006;23(3):319-29.

94. Choy MK, Movassagh M, Goh HG, Bennett MR, Down TA, Foo RS. Genome-wide conserved consensus transcription factor binding motifs are hyper-methylated. BMC Genomics. 2010;11:519.

95. Sulka B, Lortat-Jacob H, Terreux R, Letourneur F, Rousselle P. Tyrosine dephosphorylation of the syndecan-1 PDZ binding domain regulates syntenin-1 recruitment. J Biol Chem. 2009;284(16):10659-71.

96. Pereg $Y$, Shkedy D, de Graaf $P$, Meulmeester E, Edelson-Averbukh M, Salek $\mathrm{M}$, et al. Phosphorylation of Hdmx mediates its Hdm2- and ATM-dependent degradation in response to DNA damage. Proc Natl Acad Sci U S A. 2005; 102(14):5056-61.

97. Aragon E, Goerner N, Zaromytidou Al, Xi Q, Escobedo A, Massague J, et al. A Smad action turnover switch operated by WW domain readers of a phosphoserine code. Genes Dev. 2011;25(12):1275-88.

98. Oxley CL, Anthis NJ, Lowe ED, Vakonakis I, Campbell ID, Wegener KL. An integrin phosphorylation switch: the effect of beta3 integrin tail phosphorylation on Dok1 and talin binding. J Biol Chem. 2008;283(9):5420-6.

99. Spitz F, Furlong EE. Transcription factors: from enhancer binding to developmental control. Nat Rev Genet. 2012;13(9):613-26.

100. Kedde M, van Kouwenhove M, Zwart W, Oude Vrielink JA, Elkon R, Agami R. A Pumilio-induced RNA structure switch in p27-3' UTR controls miR-221 and miR-222 accessibility. Nat Cell Biol. 2010;12(10):1014-20.

101. Fiedler M, Sanchez-Barrena MJ, Nekrasov M, Mieszczanek J, Rybin V, Muller J, et al. Decoding of methylated histone $\mathrm{H3}$ tail by the Pygo-BCL9 Wnt signaling complex. Mol Cell. 2008;30(4):507-18.

102. Padrick SB, Rosen MK. Physical mechanisms of signal integration by WASP family proteins. Annu Rev Biochem. 2010;79:707-35. 
103. Zhu G, Liu Y, Shaw S. Protein kinase specificity. A strategic collaboration between kinase peptide specificity and substrate recruitment. Cell Cycle. 2005;4(1):52-6

104. Koivomagi M, Valk E, Venta R, lofik A, Lepiku M, Morgan DO, et al. Dynamics of Cdk1 substrate specificity during the cell cycle. Mol Cell. 2011;42(5):610-23.

105. Futterer K, Wong J, Grucza RA, Chan AC, Waksman G. Structural basis for Syk tyrosine kinase ubiquity in signal transduction pathways revealed by the crystal structure of its regulatory SH2 domains bound to a dually phosphorylated ITAM peptide. J Mol Biol. 1998;281(3):523-37.

106. Ti SC, Jurgenson CT, Nolen BJ, Pollard TD. Structural and biochemical characterization of two binding sites for nucleation-promoting factor WASpVCA on Arp2/3 complex. Proc Natl Acad Sci U S A. 2011;108(33):E463-71.

107. Rastinejad F, Wagner T, Zhao Q, Khorasanizadeh S. Structure of the RXR-RAR DNA-binding complex on the retinoic acid response element DR1. EMBO J. 2000;19(5):1045-54.

108. Holt LJ, Krutchinsky AN, Morgan DO. Positive feedback sharpens the anaphase switch. Nature. 2008;454(7202):353-7.

109. Lu D, Hsiao JY, Davey NE, Van Voorhis VA, Foster SA, Tang C, et al. Multiple mechanisms determine the order of APC/C substrate degradation in mitosis. J Cell Biol. 2014;207(1):23-39.

110. Mailand N, Diffley JF. CDKs promote DNA replication origin licensing in human cells by protecting Cdc6 from APC/C-dependent proteolysis. Cell. 2005:122(6):915-26.

111. Singh SA, Winter D, Kirchner M, Chauhan R, Ahmed S, Ozlu N, et al. Coregulation proteomics reveals substrates and mechanisms of $A P C / C$ dependent degradation. EMBO J. 2014;33(4):385-99.

112. Chao WC, Kulkarni K, Zhang Z, Kong EH, Barford D. Structure of the mitotic checkpoint complex. Nature. 2012;484(7393):208-13.

113. McGrath DA, Balog ER, Koivomagi M, Lucena R, Mai MV, Hirschi A, et al. Cks confers specificity to phosphorylation-dependent CDK signaling pathways. Nat Struct Mol Biol. 2013;20(12):1407-14

114. Koivomagi M, Ord M, lofik A, Valk E, Venta R, Faustova I, et al. Multisite phosphorylation networks as signal processors for Cdk1. Nat Struct Mol Biol. 2013;20(12):1415-24.

115. Jacob F. Evolution and tinkering. Science (New York, NY). 1977;196(4295):1161-6.

116. Bhattacharyya RP, Remenyi A, Yeh BJ, Lim WA. Domains, motifs, and scaffolds: the role of modular interactions in the evolution and wiring of cell signaling circuits. Annu Rev Biochem. 2006;75:655-80.

117. Boutros R, Lobjois V, Ducommun B. CDC25 phosphatases in cancer cells: key players? Good targets? Nat Rev Cancer. 2007;7(7):495-507.

118. Besson A, Dowdy SF, Roberts JM. CDK inhibitors: cell cycle regulators and beyond. Dev Cell. 2008;14(2):159-69.

119. Jung YS, Qian Y, Chen X. Examination of the expanding pathways for the regulation of p21 expression and activity. Cell Signal. 2010;22(7):1003-12.

120. Slattery M, Zhou T, Yang L, Dantas Machado AC, Gordan R, Rohs R. Absence of a simple code: how transcription factors read the genome. Trends Biochem Sci. 2014;39(9):381-99.

121. Moore MJ. From birth to death: the complex lives of eukaryotic mRNAs. Science (New York, NY). 2005;309(5740):1514-8.

122. Beltrao P, Serrano L. Specificity and evolvability in eukaryotic protein interaction networks. PLoS Comput Biol. 2007;3(2):e25.

123. Suijkerbuijk SJ, van Dam TJ, Karagoz GE, von Castelmur E, Hubner NC, Duarte AM, et al. The vertebrate mitotic checkpoint protein BUBR1 is an unusual pseudokinase. Dev Cell. 2012;22(6):1321-9.

124. Conti E, Kuriyan J. Crystallographic analysis of the specific yet versatile recognition of distinct nuclear localization signals by karyopherin alpha. Structure. 2000;8(3):329-38.

125. Dang CV, Lee WM. Identification of the human c-myc protein nuclear translocation signal. Mol Cell Biol. 1988;8(10):4048-54

126. Zhang F, White RL, Neufeld KL. Phosphorylation near nuclear localization signal regulates nuclear import of adenomatous polyposis coli protein. Proc Natl Acad Sci U S A. 2000;97(23):12577-82.

127. Welcker M, Orian A, Grim JE, Eisenman RN, Clurman BE. A nucleolar isoform of the Fbw7 ubiquitin ligase regulates c-Myc and cell size. Curr Biol. 2004; 14(20):1852-7.

128. Chen CF, Li S, Chen Y, Chen PL, Sharp ZD, Lee WH. The nuclear localization sequences of the BRCA1 protein interact with the importin-alpha subunit of the nuclear transport signal receptor. J Biol Chem. 1996;271(51):32863-8.

129. Moorthy AK, Ghosh G. p105.Ikappa Bgamma and prototypical Ikappa Bs use a similar mechanism to bind but a different mechanism to regulate the subcellular localization of NF-kappa B. J Biol Chem. 2003;278(1):556-66.
130. Klement IA, Skinner PJ, Kaytor MD, Yi H, Hersch SM, Clark HB, et al. Ataxin-1 nuclear localization and aggregation: role in polyglutamine-induced disease in SCA1 transgenic mice. Cell. 1998;95(1):41-53.

131. Lowe ED, Tews I, Cheng KY, Brown NR, Gul S, Noble ME, et al. Specificity determinants of recruitment peptides bound to phospho-CDK2/cyclin A. Biochemistry. 2002;41(52):15625-34

132. Chen IT, Akamatsu M, Smith ML, Lung FD, Duba D, Roller PP, et al Characterization of p21Cip1/Waf1 peptide domains required for cyclin E/Cdk2 and PCNA interaction. Oncogene. 1996;12(3):595-607.

133. Adams PD, Li X, Sellers WR, Baker KB, Leng X, Harper JW, et al. Retinoblastoma protein contains a C-terminal motif that targets it for phosphorylation by cyclin-cdk complexes. Mol Cell Biol. 1999;19(2):1068-80.

134. Cheng KY, Noble ME, Skamnaki V, Brown NR, Lowe ED, Kontogiannis L, et al. The role of the phospho-CDK2/cyclin A recruitment site in substrate recognition. J Biol Chem. 2006;281(32):23167-79.

135. Saha P, Eichbaum Q, Silberman ED, Mayer BJ, Dutta A. p21CIP1 and Cdc25A: competition between an inhibitor and an activator of cyclin-dependent kinases. Mol Cell Biol. 1997;17(8):4338-45.

136. Yang J, Cron P, Good VM, Thompson V, Hemmings BA, Barford D. Crystal structure of an activated Akt/protein kinase B ternary complex with GSK3peptide and AMP-PNP. Nat Struct Biol. 2002;9(12):940-4.

137. Kataoka J, Habuka N, Miyano M, Masuta C, Koiwai A. Adenine depurination and inactivation of plant ribosomes by an antiviral protein of Mirabilis jalapa (MAP). Plant Mol Biol. 1992;20(6):1111-9.

138. Cardone MH, Roy N, Stennicke HR, Salvesen GS, Franke TF, Stanbridge E, et al. Regulation of cell death protease caspase-9 by phosphorylation. Science (New York, NY). 1998;282(5392):1318-21.

139. Obsil T, Ghirlando R, Anderson DE, Hickman AB, Dyda F. Two 14-3-3 binding motifs are required for stable association of Forkhead transcription factor FOXO4 with 14-3-3 proteins and inhibition of DNA binding. Biochemistry. 2003;42(51):15264-72.

140. Kang SS, Kwon T, Kwon DY, Do SI. Akt protein kinase enhances human telomerase activity through phosphorylation of telomerase reverse transcriptase subunit. J Biol Chem. 1999;274(19):13085-90.

141. Pekarsky Y, Hallas C, Palamarchuk A, Koval A, Bullrich F, Hirata Y, et al. Akt phosphorylates and regulates the orphan nuclear receptor Nur77. Proc Natl Acad Sci U S A. 2001;98(7):3690-4.

142. Gulbis JM, Kelman Z, Hurwitz J, O'Donnell M, Kuriyan J. Structure of the C-terminal region of p21(WAF1/CIP1) complexed with human PCNA. Cell. 1996;87(2):297-306.

143. Warbrick E, Lane DP, Glover DM, Cox LS. Homologous regions of Fen1 and p21Cip1 compete for binding to the same site on PCNA: a potential mechanism to co-ordinate DNA replication and repair. Oncogene. 1997;14(19):2313-21.

144. Bruning JB, Shamoo Y. Structural and thermodynamic analysis of human PCNA with peptides derived from DNA polymerase-delta p66 subunit and flap endonuclease-1. Structure. 2004;12(12):2209-19.

145. Montecucco A, Rossi R, Levin DS, Gary R, Park MS, Motycka TA, et al. DNA ligase I is recruited to sites of DNA replication by an interaction with proliferating cell nuclear antigen: identification of a common targeting mechanism for the assembly of replication factories. EMBO J. 1998;17(13):3786-95.

146. Chuang LS, lan HI, Koh TW, Ng HH, Xu G, Li BF. Human DNA-(cytosine-5) methyltransferase-PCNA complex as a target for p21WAF1. Science (New York, NY). 1997;277(5334):1996-2000.

147. Warbrick E. The puzzle of PCNA's many partners. Bioessays. 2000;22(11):997-1006.

148. lakova P, Wang GL, Timchenko L, Michalak M, Pereira-Smith OM, Smith JR, et al. Competition of CUGBP1 and calreticulin for the regulation of p21 translation determines cell fate. EMBO J. 2004;23(2):406-17.

149. Pierce M, Benjamin KR, Montano SP, Georgiadis MM, Winter E, Vershon AK. Sum 1 and Ndt80 proteins compete for binding to middle sporulation element sequences that control meiotic gene expression. Mol Cell Biol. 2003;23(14):4814-25.

150. Zhou X, O'Shea EK. Integrated approaches reveal determinants of genomewide binding and function of the transcription factor Pho4. Mol Cell. 2011;42(6):826-36.

151. Nan X, Cross S, Bird A. Gene silencing by methyl-CpG-binding proteins. Novartis Found Symp. 1998;214:6-16. discussion -21, 46-50.

152. Hu S, Wan J, Su Y, Song Q, Zeng Y, Nguyen HN, et al. DNA methylation presents distinct binding sites for human transcription factors. Elife. 2013;2:e00726.

153. Fu Y, Dominissini D, Rechavi G, He C. Gene expression regulation mediated through reversible m(6)A RNA methylation. Nat Rev Genet. 2014;15(5):293-306. 
154. Seet BT, Dikic I, Zhou MM, Pawson T. Reading protein modifications with interaction domains. Nat Rev Mol Cell Biol. 2006;7(7):473-83.

155. Shlyueva D, Stampfel G, Stark A. Transcriptional enhancers: from properties to genome-wide predictions. Nat Rev Genet. 2014;15(4):272-86.

156. Enquist-Newman M, Sullivan M, Morgan DO. Modulation of the mitotic regulatory network by APC-dependent destruction of the Cdh1 inhibitor Acm1. Mol Cell. 2008;30(4):437-46.

157. den Elzen N, Pines J. Cyclin A is destroyed in prometaphase and can delay chromosome alignment and anaphase. J Cell Biol. 2001;153(1):121-36.

158. Zur A, Brandeis M. Securin degradation is mediated by fzy and fzr, and is required for complete chromatid separation but not for cytokinesis. EMBO J. 2001;20(4):792-801.

159. el-Deiry WS, Tokino T, Velculescu VE, Levy DB, Parsons R, Trent JM, et al. WAF1, a potential mediator of p53 tumor suppression. Cell. 1993;75(4):817-25.

160. Emamzadah S, Tropia L, Halazonetis TD. Crystal structure of a multidomain human p53 tetramer bound to the natural CDKN1A (p21) p53-response element. Mol Cancer Res. 2011;9(11):1493-9.

161. Jung P, Menssen A, Mayr D, Hermeking H. AP4 encodes a C-MYC-inducible repressor of p21. Proc Natl Acad Sci U S A. 2008;105(39):15046-51.

162. Tanaka T, Suh KS, Lo AM, De Luca LM. p21WAF1/CIP1 is a common transcriptional target of retinoid receptors: pleiotropic regulatory mechanism through retinoic acid receptor (RAR)/retinoid $X$ receptor (RXR) heterodimer and RXR/RXR homodimer. J Biol Chem. 2007;282(41):29987-97.

163. Liu M, lavarone A, Freedman LP. Transcriptional activation of the human p21(WAF1/CIP1) gene by retinoic acid receptor. Correlation with retinoid induction of U937 cell differentiation. J Biol Chem. 1996;271(49):31723-8.

164. Liu M, Lee MH, Cohen M, Bommakanti M, Freedman LP. Transcriptional activation of the Cdk inhibitor p21 by vitamin D3 leads to the induced differentiation of the myelomonocytic cell line U937. Genes Dev. 1996;10(2):142-53.

165. Chin YE, Kitagawa M, Su WC, You ZH, Iwamoto Y, Fu XY. Cell growth arrest and induction of cyclin-dependent kinase inhibitor p21 WAF1/CIP1 mediated by STAT1. Science (New York, NY). 1996;272(5262):719-22.

166. Bellido T, O'Brien CA, Roberson PK, Manolagas SC. Transcriptional activation of the p21(WAF1, CIP1, SDI1) gene by interleukin- 6 type cytokines. A prerequisite for their pro-differentiating and anti-apoptotic effects on human osteoblastic cells. J Biol Chem. 1998;273(33):21137-44.

167. Bai YQ, Miyake S, Iwai T, Yuasa Y. CDX2, a homeobox transcription factor, upregulates transcription of the p21/WAF1/CIP1 gene. Oncogene. 2003;22(39):7942-9.

168. Prince S, Carreira S, Vance KW, Abrahams A, Goding CR. Tbx2 directly represses the expression of the p21(WAF1) cyclin-dependent kinase inhibitor. Cancer Res. 2004;64(5):1669-74.

169. Chinery R, Brockman JA, Peeler MO, Shyr Y, Beauchamp RD, Coffey RJ. Antioxidants enhance the cytotoxicity of chemotherapeutic agents in colorectal cancer: a p53-independent induction of p21WAF1/CIP1 via C/EBPbeta. Nat Med. 1997;3(11):1233-41.

170. Biggs JR, Kudlow JE, Kraft AS. The role of the transcription factor Sp1 in regulating the expression of the WAF1/CIP1 gene in U937 leukemic cells. J Biol Chem. 1996;271(2):901-6.

171. Datto $M B, Y u Y$, Wang XF. Functional analysis of the transforming growth factor beta responsive elements in the WAF1/Cip1/p21 promoter. J Biol Chem. 1995;270(48):28623-8.

172. Moustakas A, Kardassis D. Regulation of the human p21/WAF1/Cip1 promoter in hepatic cells by functional interactions between Sp1 and Smad family members. Proc Natl Acad Sci U S A. 1998;95(12):6733-8.

173. Billon N, Carlisi D, Datto MB, van Grunsven LA, Watt A, Wang XF, et al. Cooperation of Sp1 and p300 in the induction of the CDK inhibitor p21WAF1/CIP1 during NGF-mediated neuronal differentiation. Oncogene. 1999;18(18):2872-82.

174. Zeng YX, Somasundaram K, el-Deiry WS. AP2 inhibits cancer cell growth and activates p21WAF1/CIP1 expression. Nat Genet. 1997;15(1):78-82.

175. Hiyama H, lavarone A, Reeves SA. Regulation of the cdk inhibitor p21 gene during cell cycle progression is under the control of the transcription factor E2F. Oncogene. 1998;16(12):1513-23.

176. Liu R, Wang L, Chen G, Katoh H, Chen C, Liu Y, et al. FOXP3 up-regulates p21 expression by site-specific inhibition of histone deacetylase 2/histone deacetylase 4 association to the locus. Cancer Res. 2009;69(6):2252-9.

177. Joseph B, Orlian M, Furneaux H. p21(waf1) mRNA contains a conserved element in its $3^{\prime}$-untranslated region that is bound by the Elav-like mRNAstabilizing proteins. J Biol Chem. 1998;273(32):20511-6.
178. Wang W, Furneaux $H$, Cheng $H$, Caldwell MC, Hutter D, Liu Y, et al. HuR regulates p21 mRNA stabilization by UV light. Mol Cell Biol. 2000;20(3):760-9.

179. Shu L, Yan W, Chen X. RNPC1, an RNA-binding protein and a target of the p53 family, is required for maintaining the stability of the basal and stressinduced p21 transcript. Genes Dev. 2006;20(21):2961-72.

180. Battelli C, Nikopoulos GN, Mitchell JG, Verdi JM. The RNA-binding protein Musashi-1 regulates neural development through the translational repression of p21WAF-1. Mol Cell Neurosci. 2006;31(1):85-96.

181. Yano M, Okano HJ, Okano H. Involvement of Hu and heterogeneous nuclear ribonucleoprotein $\mathrm{K}$ in neuronal differentiation through p21 mRNA post-transcriptional regulation. J Biol Chem. 2005;280(13):12690-9.

182. Kriwacki RW, Hengst L, Tennant L, Reed SI, Wright PE. Structural studies of p21Waf1/Cip1/Sdi1 in the free and Cdk2-bound state: conformational disorder mediates binding diversity. Proc Natl Acad Sci U S A. 1996;93(21):11504-9.

183. Nishitani $H$, Shiomi $Y$, lida H, Michishita M, Takami T, Tsurimoto T. CDK inhibitor p21 is degraded by a proliferating cell nuclear antigen-coupled Cul4-DDB1Cdt2 pathway during S phase and after UV irradiation. J Biol Chem. 2008;283(43):29045-52.

184. Zhang L, Mei Y, Fu NY, Guan L, Xie W, Liu HH, et al. TRIM39 regulates cell cycle progression and DNA damage responses via stabilizing p21. Proc Natl Acad Sci U S A. 2012;109(51):20937-42.

185. Amador V, Ge S, Santamaria PG, Guardavaccaro D, Pagano M. APC/C(Cdc20) controls the ubiquitin-mediated degradation of p21 in prometaphase. Mol Cell. 2007;27(3):462-73.

186. Cayrol C, Knibiehler M, Ducommun B. p21 binding to PCNA causes G1 and G2 cell cycle arrest in p53-deficient cells. Oncogene. 1998;16(3):311-20.

187. Wohlschlegel JA, Dwyer BT, Takeda DY, Dutta A. Mutational analysis of the Cy motif from p21 reveals sequence degeneracy and specificity for different cyclin-dependent kinases. Mol Cell Biol. 2001;21(15):4868-74.

188. Zhu H, Nie L, Maki CG. Cdk2-dependent Inhibition of p21 stability via a C-terminal cyclin-binding motif. J Biol Chem. 2005;280(32):29282-8.

189. Rodriguez-Vilarrupla A, Diaz C, Canela N, Rahn HP, Bachs O, Agell N. Identification of the nuclear localization signal of p21(cip1) and consequences of its mutation on cell proliferation. FEBS Lett. 2002;531(2):319-23.

190. Zhou BP, Liao Y, Xia W, Spohn B, Lee MH, Hung MC. Cytoplasmic localization of p21Cip1/WAF1 by Akt-induced phosphorylation in HER-2/ neu-overexpressing cells. Nat Cell Biol. 2001;3(3):245-52.

191. Rossig L, Jadidi AS, Urbich C, Badorff C, Zeiher AM, Dimmeler S. Aktdependent phosphorylation of p21(Cip1) regulates PCNA binding and proliferation of endothelial cells. Mol Cell Biol. 2001;21(16):5644-57.

192. Cornils H, Kohler RS, Hergovich A, Hemmings BA. Human NDR kinases control $\mathrm{G}(1) / \mathrm{S}$ cell cycle transition by directly regulating p21 stability. Mol Cell Biol. 2011:31(7):1382-95.

193. Bornstein G, Bloom J, Sitry-Shevah D, Nakayama K, Pagano M, Hershko A Role of the SCFSkp2 ubiquitin ligase in the degradation of p21Cip1 in S phase. J Biol Chem. 2003;278(28):25752-7.

194. Wang W, Nacusi L, Sheaff RJ, Liu X. Ubiquitination of p21Cip1/WAF1 by SCFSkp2: substrate requirement and ubiquitination site selection. Biochemistry. 2005:44(44):14553-64.

195. Mayer BJ. SH3 domains: complexity in moderation. J Cell Sci. 2001;114(Pt 7):1253-63.

196. Heery DM, Kalkhoven E, Hoare S, Parker MG. A signature motif in transcriptional co-activators mediates binding to nuclear receptors. Nature. 1997;387(6634):733-6.

197. Brown MC, Curtis MS, Turner CE. Paxillin LD motifs may define a new family of protein recognition domains. Nat Struct Biol. 1998;5(8):677-8.

198. Dahiya A, Gavin MR, Luo RX, Dean DC. Role of the LXCXE binding site in Rb function. Mol Cell Biol. 2000;20(18):6799-805

199. Main AL, Harvey TS, Baron M, Boyd J, Campbell ID. The three-dimensional structure of the tenth type III module of fibronectin: an insight into RGDmediated interactions. Cell. 1992;71(4):671-8.

200. Guttler T, Madl T, Neumann P, Deichsel D, Corsini L, Monecke T, et al. NES consensus redefined by structures of PKI-type and Rev-type nuclear export signals bound to CRM1. Nat Struct Mol Biol. 2010;17(11):1367-76.

201. Pelham HR. The retention signal for soluble proteins of the endoplasmic reticulum. Trends Biochem Sci. 1990;15(12):483-6.

202. Geng L, Okuhara D, Yu Z, Tian X, Cai Y, Shibazaki S, et al. Polycystin-2 traffics to cilia independently of polycystin-1 by using an N-terminal RVXP motif. J Cell Sci. 2006;119(Pt 7):1383-95.

203. Gould SJ, Keller GA, Hosken N, Wilkinson J, Subramani S. A conserved tripeptide sorts proteins to peroxisomes. J Cell Biol. 1989;108(5):1657-64. 
204. Opresko LK, Chang CP, Will BH, Burke PM, Gill GN, Wiley HS. Endocytosis and lysosomal targeting of epidermal growth factor receptors are mediated by distinct sequences independent of the tyrosine kinase domain. J Biol Chem. 1995;270(9):4325-33.

205. Zhu L, Harlow E, Dynlacht BD. p107 uses a p21CIP1-related domain to bind cyclin/cdk2 and regulate interactions with E2F. Genes Dev. 1995;9(14):1740-52.

206. Egloff MP, Johnson DF, Moorhead G, Cohen PT, Cohen P, Barford D. Structural basis for the recognition of regulatory subunits by the catalytic subunit of protein phosphatase 1. EMBO J. 1997;16(8):1876-87.

207. Sbodio Jl, Chi NW. Identification of a tankyrase-binding motif shared by IRAP, TAB182, and human TRF1 but not mouse TRF1. NuMA contains this RXXPDG motif and is a novel tankyrase partner. J Biol Chem. 2002;277(35):31887-92.

208. Sheng Y, Saridakis V, Sarkari F, Duan S, Wu T, Arrowsmith CH, et al. Molecular recognition of p53 and MDM2 by USP7/HAUSP. Nat Struct Mol Biol. 2006;13(3):285-91.

209. Qi S, O'Hayre M, Gutkind JS, Hurley JH. Structural and biochemical basis for ubiquitin ligase recruitment by arrestin-related domain-containing protein-3 (ARRDC3). J Biol Chem. 2014;289(8):4743-52.

210. Glotzer M, Murray AW, Kirschner MW. Cyclin is degraded by the ubiquitin pathway. Nature. 1991;349(6305):132-8.

211. Havens CG, Walter JC. Docking of a specialized PIP Box onto chromatinbound PCNA creates a degron for the ubiquitin ligase CRL4Cdt2. Mol Cell. 2009;35(1):93-104.

212. Hao B, Oehlmann S, Sowa ME, Harper JW, Pavletich NP. Structure of a Fbw7-Skp1-cyclin E complex: multisite-phosphorylated substrate recognition by SCF ubiquitin ligases. Mol Cell. 2007;26(1):131-43.

213. Min JH, Yang $H$, Ivan M, Gertler F, Kaelin Jr WG, Pavletich NP. Structure of an HIF-1alpha -pVHL complex: hydroxyproline recognition in signaling. Science (New York, NY). 2002;296(5574):1886-9.

214. Kussie PH, Gorina S, Marechal V, Elenbaas B, Moreau J, Levine AJ, et al. Structure of the MDM2 oncoprotein bound to the p53 tumor suppressor transactivation domain. Science (New York, NY). 1996;274(5289):948-53.

215. Kim ST, Lim DS, Canman CE, Kastan MB. Substrate specificities and identification of putative substrates of ATM kinase family members. J Biol Chem. 1999;274(53):37538-43.

216. Wulf G, Finn G, Suizu F, Lu KP. Phosphorylation-specific prolyl isomerization: is there an underlying theme? Nat Cell Biol. 2005;7(5):435-41.

217. Shakin-Eshleman SH, Spitalnik SL, Kasturi L. The amino acid at the $X$ position of an Asn-X-Ser sequon is an important determinant of N-linked coreglycosylation efficiency. J Biol Chem. 1996;271(11):6363-6.

218. Talanian RV, Quinlan C, Trautz S, Hackett MC, Mankovich JA, Banach D, et al. Substrate specificities of caspase family proteases. J Biol Chem. 1997;272(15):9677-82.

219. Thinon E, Serwa RA, Broncel M, Brannigan JA, Brassat U, Wright MH, et al Global profiling of co- and post-translationally N-myristoylated proteomes in human cells. Nat Commun. 2014;5:4919.

220. Cho SJ, Zhang J, Chen X. RNPC1 modulates the RNA-binding activity of, and cooperates with, HuR to regulate p21 mRNA stability. Nucleic Acids Res. 2010;38(7):2256-67.

\section{Submit your next manuscript to BioMed Central and we will help you at every step:}

- We accept pre-submission inquiries

- Our selector tool helps you to find the most relevant journal

- We provide round the clock customer support

- Convenient online submission

- Thorough peer review

- Inclusion in PubMed and all major indexing services

- Maximum visibility for your research

Submit your manuscript at www.biomedcentral.com/submit 